\title{
Changes of Physicochemical Properties of Starch Syrups Recommended for Winter Feeding of Honeybees during Storage
}

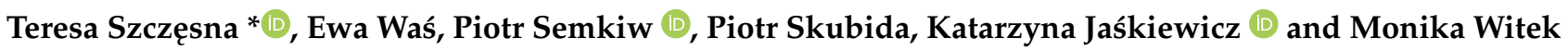 \\ The National Institute of Horticultural Research, Konstytucji 3 Maja 1/3, 96-100 Skierniewice, Poland; \\ ewa.was@inhort.pl (E.W.); piotr.semkiw@inhort.pl (P.S.); piotr.skubida@inhort.pl (P.S.); \\ katarzyna.jaskiewicz@inhort.pl (K.J.); monika.witek@inhort.pl (M.W.) \\ * Correspondence: teresa.szczesna@inhort.pl
}

Citation: Szczęsna, T.; Waś, E.;

Semkiw, P.; Skubida, P.; Jaśkiewicz, K.; Witek, M. Changes of

Physicochemical Properties of Starch Syrups Recommended for Winter Feeding of Honeybees during Storage. Agriculture 2021, 11, 374. https:/ / doi.org/10.3390/agriculture11040374

Academic Editor: Nikola Puvača

Received: 9 March 2021

Accepted: 16 April 2021

Published: 20 April 2021

Publisher's Note: MDPI stays neutral with regard to jurisdictional claims in published maps and institutional affiliations.

Copyright: (c) 2021 by the authors. Licensee MDPI, Basel, Switzerland. This article is an open access article distributed under the terms and conditions of the Creative Commons Attribution (CC BY) license (https:// creativecommons.org/licenses/by/ $4.0 /)$.
Abstract: The aim of this study was to determine the influence of storage temperature and time on physicochemical parameters of starch syrups recommended for the winter feeding of bee colonies. The studies included commercially available three starch syrups and an inverted saccharose syrup that were stored at different temperatures: ca. $20{ }^{\circ} \mathrm{C}, 10-14{ }^{\circ} \mathrm{C}$, and ca. $4{ }^{\circ} \mathrm{C}$. Physicochemical parameters of fresh syrups (immediately after purchase) and syrups after 3, 6, 9, 12, 15, 18, 21, and 24 months of storage at the abovementioned temperatures were measured. It was observed that the rate of unfavorable changes in chemical composition of starch syrups and the inverted saccharose syrup, mainly the changes in the 5-hydroxymethylfurfural (HMF) content, depended on the type of a syrup and storage conditions (temperature, time). Properties of tested starch syrups intended for winter feeding of bees stored at ca. $20{ }^{\circ} \mathrm{C}$ maintained unchanged for up to 6 months, whereas the same syrups stored at lower temperatures $\left(10-14{ }^{\circ} \mathrm{C}\right)$ maintained unchanged physicochemical parameters for about 12 months. In higher temperatures, the HMF content increased. To date, the influence of this compound on bees has not been thoroughly investigated.

Keywords: honeybee colony; physicochemical parameters; HMF; inverted saccharose syrup; starch syrup; storage

\section{Introduction}

When natural carbohydrate foods are insufficient (when nectar flow is not available, during long-term unfavorable rainy weather or drought) and when colony's demand for such foods is high, e.g., when bees gather food for winter, commercially available carbohydrate foods (inverted saccharose syrups and starch syrups, High-Fructose Corn Syrup (HFCS)) are good alternatives for the beet sugar [1-14]. Knowledge on the physicochemical compositions of these syrups and their suitability for winter feeding of bees is still not sufficient. In addition, storage conditions and shelf life in the context of suitability for feeding bees have not been studied. During storage of these syrups, sugars composition (influencing the process of crystallization) and other chemical characteristics such as $\mathrm{pH}$, acidity, and 5-hydroxymethylfurfural (HMF) content may change.

Chemically, the 5-hydroxymethylfurfural (HMF) is a six-carbon heterocyclic organic compound containing two functional groups, an aldehyde and alcohol group. It is formed in many foods in the reaction of dehydration of monosaccharides, namely hexoses, occurring in acidic conditions (the so-called caramelization) and as one of the final products of the Maillard reaction (the so-called nonenzymatic browning). This reaction occurs during heat treatment of sugar-rich foods [15-19]. Despite the fact that HMF is a well-known chemical compound appearing during heat treatment of different types of foods, its influence on human and bee health is still a controversial issue. Many studies have shown its toxic, mutagenic, and cancerogenic properties. However, there are also reports on its antioxidant, antiallergic, and even anticancer properties for the human organism [17-20]. 
HMF forms during the production of syrups intended for the winter feeding of bees and its content in the final product depends on temperature, $\mathrm{pH}$, and acidity $[13,18,21]$. Regardless of the source of those foods, they are not always safe, because HMF and its metabolites constitute a potential threat to honeybees. High HMF concentration in products used for winter feeding can disrupt the normal functioning of bee colonies $[2,4,9,13,18,19,21-27]$. According to many of the abovementioned authors, this compound is toxic to bees. After 15-30 days of feeding Apis mellifera carnica workers with syrups containing different HMF concentrations $(100 \mathrm{mg} / \mathrm{kg}, 500 \mathrm{mg} / \mathrm{kg}, 1000 \mathrm{mg} / \mathrm{kg}$, and $1500 \mathrm{mg} / \mathrm{kg})$, midgut cells necrosis and increased mortality were found [27]. Other studies have not shown negative influence of feeding bees with sugar syrups containing $400 \mathrm{mg} / \mathrm{L}$ of this compound when it comes to bees' survivability, even when the bees were infested with Varroa destructor [21]. It was observed, however, that high mortality can be caused by high HMF content in sugar syrup acidified with $\mathrm{HCl}(10,000 \mathrm{mg} / \mathrm{L})$. Based on the results of the studies conducted to date, it was assumed that HMF content in products used to feed bees should not exceed $30 \mathrm{mg} / \mathrm{kg}$.

It is a common beekeeping practice to store winter food for bees, because these products are usually bought far before their utilization in the apiaries as the prices are usually lower before the season. In addition, beekeepers simply have more time before the period of intense works in the apiaries. Sometimes, some amounts of the product unused in previous beekeeping season are stored to the next season, exceeding the shelf life recommended by the manufacturers.

Previous studies on the changes in chemical composition, especially the kinetics of HMF formation and degradation reactions, have mainly concerned honey [16,18,28-41]. Concentration of this compound increases during heat treatment of honey, especially in higher temperatures (e.g., during decrystallization) and during storage. A logarithmic relation was found between the HMF content in honey and storage time [41]. Studies also showed that initial amount of HMF has no influence on the kinetics of HMF formation in honey [28]. In varietal honeys, HMF formation rate is highly correlated to the decrease in $\mathrm{pH}$ and increase in total acidity [31,32]. During storage at different temperatures, research has shown that HMF content in some honey varieties (citrus, chestnut, buckwheat, phacelia, and multifloral) decreased $[16,29,31,32]$. The authors have explained this decrease in HMF content with the intensification of the complex processes of degradation of this compound with simultaneous slowdown of formation of HMF precursors while storing the honey in different conditions.

Few reports have shown different reactions of syrup quality parameters to storage conditions $[9,21,42]$. High HMF content (up to $102.3 \mathrm{mg} / \mathrm{kg}$ ) was found in syrups stored for a long time outside, in a place exposed to high ambient temperatures, despite the fact that fresh syrups contained low concentration of this component [42]. According to Le Blanc et al. [9], storing fresh HFCS syrups with a starting HMF content of $3.1-28.7 \mathrm{mg} / \mathrm{kg}$ for 36 days at $49^{\circ} \mathrm{C}$ resulted in an increase in HMF content, with HMF content reaching over $200 \mathrm{mg} / \mathrm{kg}$. Moreover, at $69^{\circ} \mathrm{C}, \mathrm{HMF}$ content was found to increase to over $30,000 \mathrm{mg} / \mathrm{kg}$. Frizzera et al. [21] showed that acidification of sugar syrup with hydrochloric acid to $\mathrm{pH}=2$ had significant impact on the rate of HMF formation during heat treatment at $110{ }^{\circ} \mathrm{C}$. Content of this compound increased from $1786.7 \mathrm{mg} / \mathrm{L}$ after $10 \mathrm{~min}$ to $14,366.7 \mathrm{mg} / \mathrm{L}$ after next $40 \mathrm{~min}$ of heating at this temperature.

Due to the lack of sufficient and full information on the stability of physical properties and chemical composition of starch syrups during storage, there is a necessity to conduct detailed studies on this subject matter. The aim of this study was to determine the influence of storage temperature and time on physicochemical parameters of starch syrups used for the winter feeding of bees. The studies presented in this paper are a continuation of the studies on the physicochemical composition of starch syrups and stores produced by bees from those syrups [43]. In both cases, laboratory tests were conducted on the same starch syrups. 
Monitoring of HMF content in products recommended for the winter feeding of bees is especially important due to its potential toxic effect on bees supported by the abovementioned literature data. Manufacturers' declarations concerning storage conditions and shelf life are not clear and lack support of detailed studies.

\section{Materials and Methods}

\subsection{Material}

Stability of physicochemical parameters of syrups recommended for the winter feeding of bees was analyzed in the Bee Products Quality Testing Laboratory of The National Institute of Horticultural Research, Apiculture Division in Puławy, Poland. The experimental material consisted of 3 commercially available starch syrups (Apifortune-manufactured in France, ICKO Apiculture; Apikel 20-manufactured in Germany, Kellman Produktions $\mathrm{GmbH}$; Apifood-manufactured in Poland, PPHU Orion-Jarosław Kasprzyk) and an inverted saccharose syrup (Apiinvert-manufactured in Germany, Südzucker AG). The term "starch syrups" is used for tested syrups (Apifortune, Apikel 20 and Apifood) because they are made of starch (cereals) and to make them easier to distinguish from inverted saccharose syrup (Apiinvert). The products were ordered from the manufacturers or distributors and came directly from the production line. The transport via a courier company lasted no longer than 1 week. The influence of the following temperatures was tested: ca. $20^{\circ} \mathrm{C}\left(18-24{ }^{\circ} \mathrm{C}\right), 10-14{ }^{\circ} \mathrm{C}$, and ca. $4{ }^{\circ} \mathrm{C}\left(2-8{ }^{\circ} \mathrm{C}\right)$. Physicochemical parameters were determined in fresh syrups (immediately after the purchase) and after 3, 6, 9, 12, 15, 18, 21, and 24 months of storage at the abovementioned temperatures. The tests were conducted twice - on samples of the same types of syrups purchased from the same manufactures-in 2012 and 2013. Three repetitions of determination of a certain parameter per each sample were conducted.

\subsection{Methods}

The following physicochemical parameters were determined in the samples of fresh and stored syrups: water content (refractometric method), $\mathrm{pH}$ and free acidity (potentiometric titration), electrical conductivity (conductometric method), HMF content (HPLC-UV), and sugars contents (fructose, glucose, saccharose, maltose, maltotriose and erlose (HPLCRI). These analyses were conducted according to analytical methods established by the International Honey Commission [44] and modified by Szczęsna et al. [36].

The water content was determined by a refractometric method using a thermostated Atago RX-5000 $\alpha$ digital refractometer (ATAGO CO., LTD., Tokyo, Japan). Water measurements were performed at $20^{\circ} \mathrm{C}$.

Sugars, including monosaccharides (glucose and fructose), disaccharides (saccharose, turanose, maltose, trehalose, isomaltose), and trisaccharides (erlose, and maltotriose), were determined by a high-performance liquid chromatography technique with a refractometric detector (HPLC-RI). The Shimadzu HPLC system (SHIMADZU CO., Kyoto, Japan), consisting of an LC-10ADVP Pump, CTO-10ASVP Column Oven, SIL-10ADVP Auto Injector, RID-10A Refractive Index Detector, and PhenoSphere LC column, NH2 $80 \AA$, $250 \times 4.6 \mathrm{~mm}$ (Phenomenex Inc., Torrance, CA, USA), was used for this analysis. The HPLC system was run using computer software in the following conditions: flow rate, $1.5 \mathrm{~mL} / \mathrm{min}$; mobile phase acetonitrile:water $(80: 20 \mathrm{v} / \mathrm{v})$; column and detector temperature, $30^{\circ} \mathrm{C}$; and injection volume, $20 \mu \mathrm{L}$. The sugars were identified through the comparison of individual sugars retention times of the reference and the analyzed solution. The quantitative assays were conducted using the external standard method comparing peak surfaces of these sugars. The results are expressed as $\mathrm{g} / 100 \mathrm{~g}$ to 1 decimal place.

HMF content was determined by a high-performance liquid chromatography technique with a UV detector (HPLC-UV). The Knauer HPLC system (KNAUER GmbH, Berlin, Germany) consisting of HPLC K-501 and K-1001 pumps, Degasser, Dynamic Mixing Chamber, 3800 Autosampler and UV K-2501 Detector, and Eurospher $100 \AA$, 5 um C18 Vertex 
Plus Column (BGB Analytik Vertrieb GmbH, Lörrach, Germany), was used for this analysis. An external standard method for the quantitative analysis of HMF was applied.

Free acidity was determined by the potentiometric titration method, and $\mathrm{pH}$ was determined by the potentiometric method using a DL50 Titrator equipped with a Rondolino autosampler (Metler Toledo GmbH, Greifensee, Switzerland).

Electrical conductivity was determined by the conductometric method using a WTW inoLAB Cond 700 conductometer (WTW, Weilheim, Germany). The results for electrical conductivity were calculated using a temperature correction factor of $2.6 \% /{ }^{\circ} \mathrm{C}$.

In addition, content of maltodextrins (DP4-DP7) was determined using the HPLC-RI, according to the method developed by Rybak-Chmielewska et al. [7]. Chromatographic separation was performed using the Shimadzu HPLC system (the same as for sugar analysis) and the Luna column, $5 \mu \mathrm{m}$ NH2 $100 \AA, 250 \times 4.60 \mathrm{~mm}$ (Phenomenex Inc., Torrance, CA, USA). The mobile phase acetonitrile:water $(65: 35 \mathrm{v} / \mathrm{v})$, flow rate of $3 \mathrm{~mL} / \mathrm{min}$, and temperature of $40{ }^{\circ} \mathrm{C}$ for the column and detector were applied for maltodextrins separation. The quantitative analyses of maltodextrins (DP4-DP7) were performed by the external standard method. Maltodextrins composed of 4 to 7 glucose molecules (maltotetraose (DP4), maltopentaose (DP5), maltohexaose (DP6), and maltoheptaose (DP7)) were determined.

\section{Results}

Some of the physicochemical parameters of fresh starch syrups (Apifortune, Apikel 20, Apifood) and inverted saccharose syrup (Apiinvert) recommended as winter food for bee colonies used in our study are presented in Table 1 . These parameters slightly differed from the values declared by manufacturers on the product labels [11]. The particular differences among tested syrups concerned the quantitative content of individual sugars (fructose, glucose, saccharose, maltose, maltotriose) and the content of HMF and $\mathrm{pH}$ values.

Table 1. Physicochemical parameters of starch syrups (Apifortune, Apikel 20, Apifood) and inverted saccharose syrup (Apiinvert).

\begin{tabular}{|c|c|c|c|c|c|c|c|c|c|c|c|c|}
\hline \multirow{3}{*}{ Parameter } & \multirow{2}{*}{\multicolumn{6}{|c|}{$\begin{array}{l}\text { Starch Syrups } \\
\text { Apikel } 20\end{array}$}} & \multirow{2}{*}{\multicolumn{3}{|c|}{ Apifood }} & \multirow{2}{*}{\multicolumn{3}{|c|}{$\begin{array}{c}\text { Inverted Saccharose Syrup } \\
\text { Apiinvert }\end{array}$}} \\
\hline & & & & & & & & & & & & \\
\hline & 2012 & 2013 & DDM * & 2012 & 2013 & DDM * & 2012 & 2013 & DDM * & 2012 & 2013 & DDM * \\
\hline Water (\%) & 22.9 & 22.7 & $24-26$ & 23.7 & 23.6 & $26-28$ & 19.8 & 20.9 & 22.4 & 26.5 & 26.9 & 27.8 \\
\hline $\begin{array}{l}\text { Electrical conductivity } \\
(\mathrm{mS} / \mathrm{cm})\end{array}$ & 0.02 & 0.01 & No data & 0.01 & 0.02 & No data & 0.01 & 0.01 & No data & 0.05 & 0.01 & No data \\
\hline $\mathrm{pH}$ & 4.11 & 4.50 & No data & 4.35 & 4.89 & No data & 4.21 & 4.46 & No data & 3.80 & 4.52 & No data \\
\hline Free acids (mval/kg) & 4.9 & 1.2 & No data & 5.5 & 1.2 & No data & 4.0 & 1.3 & No data & 5.9 & 0.9 & No data \\
\hline Fructose $(\mathrm{g} / 100 \mathrm{~g})$ & 18.2 & 18.2 & 18.8 & 11.7 & 13.5 & $11.7-14.6$ & 20.1 & 21.0 & $17.1-21.7$ & 35.5 & 28.0 & 28.2 \\
\hline Glucose (g/100 g) & 23.5 & 23.6 & 25.2 & 16.3 & 21.6 & 17.5 & 25.2 & 27.3 & $23.3-28.7$ & 29.8 & 22.7 & 22.4 \\
\hline Saccharose $(\mathrm{g} / 100 \mathrm{~g})$ & n.d.** & n.d.** & No data & n.d. ** & n.d. ** & No data & n.d. ** & n.d. ** & No data & 4.3 & 20.2 & 21.7 \\
\hline Maltose $(\mathrm{g} / 100 \mathrm{~g})$ & 16.5 & 15.8 & 15.4 & 34.6 & 21.7 & 30.7 & 23.1 & 15.9 & $13.2-18.6$ & n.d. ${ }^{* *}$ & n.d. ${ }^{* *}$ & No data \\
\hline Maltotriose $(\mathrm{g} / 100 \mathrm{~g})$ & 5.5 & 4.9 & 15.8 & 8.8 & 7.6 & 10.2 & 7.2 & 6.6 & $3.9-11.6$ & n.d. ${ }^{* *}$ & n.d. ${ }^{* *}$ & No data \\
\hline $\begin{array}{l}\text { Total of fructose and } \\
\text { glucose }(\mathrm{g} / 100 \mathrm{~g})\end{array}$ & 41.7 & 41.8 & No data & 28.0 & 35.1 & No data & 45.3 & 48.3 & No data & 65.3 & 50.7 & No data \\
\hline $\begin{array}{l}\text { Fructose to glucose ratio } \\
\qquad(\mathrm{F} / \mathrm{G})\end{array}$ & 0.77 & 0.77 & No data & 0.72 & 0.63 & No data & 0.80 & 0.77 & No data & 1.19 & 1.23 & No data \\
\hline $\begin{array}{l}\text { Total of determined sugars } \\
\qquad(\mathrm{g} / 100 \mathrm{~g})\end{array}$ & 63.7 & 63.0 & No data & 71.4 & 68.3 & No data & 77.2 & 73.4 & No data & 69.6 & 70.9 & No data \\
\hline $\begin{array}{c}\text { Maltodextrins (DP4-DP7) } \\
(\mathrm{g} / 100 \mathrm{~g})\end{array}$ & 4.9 & 4.8 & No data & 3.6 & 3.9 & No data & 3.4 & 3.2 & No data & n.d. & n.d. & No data \\
\hline $\mathrm{HMF}^{* * * *}(\mathrm{mg} / \mathrm{kg})$ & 43.3 & 39.5 & No data & 14.6 & 30.1 & to 20 & 27.2 & 51.2 & To 40 & 47.4 & 25.7 & No data \\
\hline
\end{tabular}

* data declared by manufacturers [11]; ${ }^{* *}$ not determined with determination limit $0.5 \mathrm{~g} / 100 \mathrm{~g} ;{ }^{* * *}$ not determined with determination limit $0.05 \mathrm{~g} / 100 \mathrm{~g} ;{ }^{* * * *}$ 5-hydroxymethylfurfural.

The monosaccharides, such as fructose and glucose, and the disaccharide saccharose were the main sugars in inverted saccharose syrup. In starch syrups, apart from simple sugars (fructose and glucose), there was also disaccharide maltose and trisaccharide maltotriose. The erlose was not detected in the tested syrups (at the detected limit of $0.2 \mathrm{~g} / 100 \mathrm{~g}$ ). The fructose content ranged from $11.7 \mathrm{~g}$ to $21.0 \mathrm{~g} / 100 \mathrm{~g}$ in starch syrups and from $28.0 \mathrm{~g}$ to $35.5 \mathrm{~g} / 100 \mathrm{~g}$ in inverted saccharose syrup. The glucose content in starch syrups was higher than fructose content $(F / G=0.6-0.8)$. The content of this sugar in inverted saccharose syrup was lower compared to fructose content $(F / G=1.2)$. The disaccharide, saccharose, was determined only in the fresh inverted saccharose syrup (Apiinvert), with a content of $4.3 \mathrm{~g} / 100 \mathrm{~g}$ in the syrup from 2012 and $20.2 \mathrm{~g} / 100 \mathrm{~g}$ in the 
syrup from 2013. The maltose content in starch syrups ranged from $15.8 \mathrm{~g}$ to $34.6 \mathrm{~g} / 100 \mathrm{~g}$, and the maltotriose from 4.9 to $8.8 \mathrm{~g} / 100 \mathrm{~g}$. The starch maltodextrins (DP4-DP7) were identified in starch syrups in an amount of $4.0 \mathrm{~g} / 100 \mathrm{~g}$, on average.

The HMF content ranged from $14.6 \mathrm{mg} / \mathrm{kg}$ to $51.2 \mathrm{mg} / \mathrm{kg}$ in starch syrups and from $25.7 \mathrm{mg} / \mathrm{kg}$ to $47.4 \mathrm{mg} / \mathrm{kg}$ in inverted saccharose syrup. The $\mathrm{pH}$ of starch syrups ranged from 4.11 to 4.35 (2012) and from 4.46 to 4.89 (2013) (Table 1). The value of this parameter for the inverted saccharose syrup was 3.80 and 4.52 , respectively.

Changes in chemical composition of starch syrups (Apifortune, Apikel 20, Apifood) and the inverted saccharose syrup (Apiinvert) concerned mainly HMF content, $\mathrm{pH}$, and saccharose content. The HMF content in two starch syrups (Apifortune, Apifood) and the inverted saccharose syrup (Apiinvert) increased during storage at all the tested temperatures (ca. $20^{\circ} \mathrm{C}, 10-14{ }^{\circ} \mathrm{C}$, and ca. $4^{\circ} \mathrm{C}$ ), with the highest increase found at the temperature of ca. $20^{\circ} \mathrm{C}$ (Figures 1-3). The Apikel 20 starch syrup was an exception, showing different kinetics of HMF formation during storage.

HMF content in two starch syrups in Apifortune and Apifood starch syrups purchased in 2012 increased, on average, by $12 \%$ and $16 \%$ after 12 months and $40 \%$ and $57 \%$ after 24 months of storage at the temperature of ca. $20{ }^{\circ} \mathrm{C}$ (Figure 1a). The increase in the content of this compound in these starch syrups purchased in 2013 amounted to $26 \%$ and $13 \%$ (after 12 months) and 56\% and 35\% (after 24 months) (Figure 1b). HMF content in the third tested starch syrup (Apikel 20) increased by 19\% in the syrup from 2012, whereas in the syrup from 2013, the content of this compound decreased by as much as $78 \%$. A decrease of HMF content in this syrup was found already after 9 months of storage. In the inverted saccharose syrup, after storage at ca. $20^{\circ} \mathrm{C}$ for 12 months, HMF content increased by $35 \%$ (syrup from 2012) and 56\% (syrup from 2013). After 24 months, the increase amounted to $93 \%$ (syrup from 2012) and $116 \%$ (syrup from 2013) in comparison to the fresh syrup.
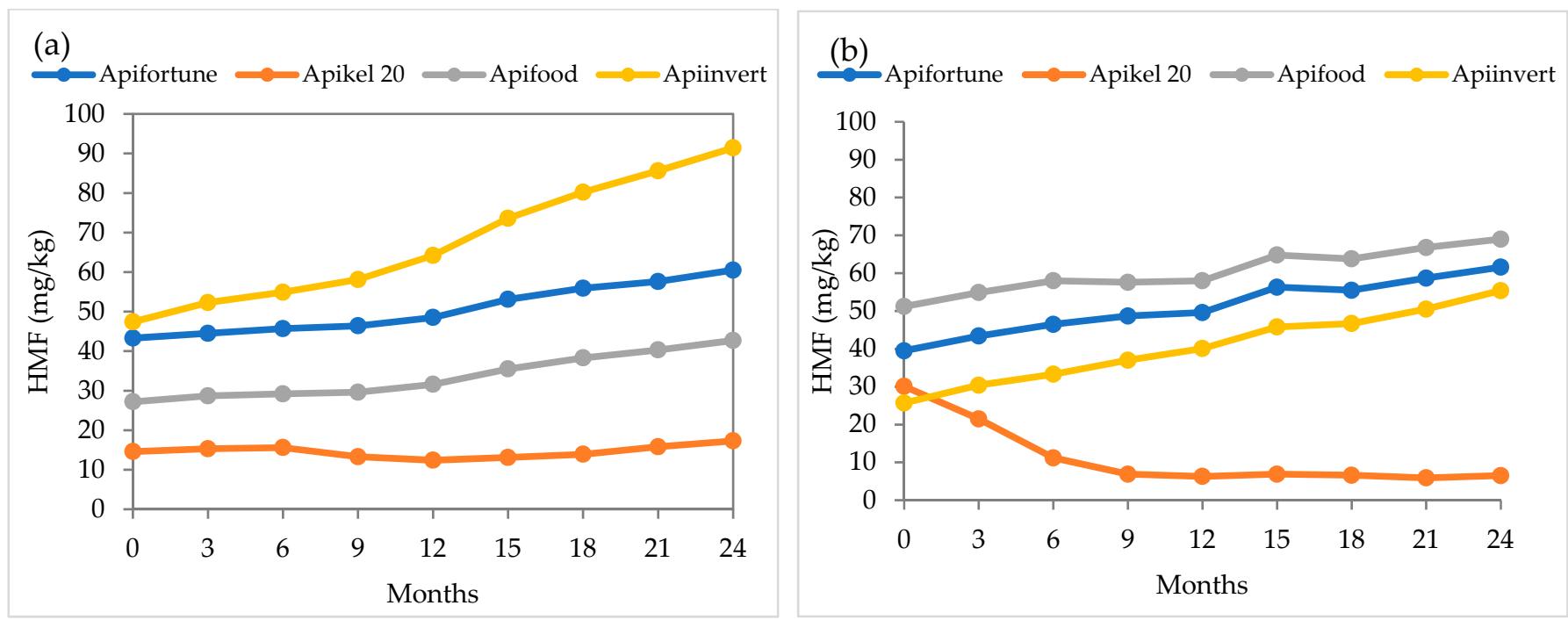

Figure 1. Changes of HMF content in syrups during storage at about $20^{\circ} \mathrm{C}$ (a) from 2012 and (b) from 2013.

Considering the temperature of $10-14{ }^{\circ} \mathrm{C}$, the highest increase in HMF content was found in the inverted saccharose syrup, in which the HMF content increased by about $20 \%$ after storage for 24 months (the average for syrups from 2012 and 2013) (Figure 2). In starch syrups, the increase in the content of this compound ranged from $2 \%$ to $6 \%$ in syrup from 2012. In syrups from 2013, HMF content increased by about $12 \%$ (the average value). In the Apikel 20 starch syrup, similarly stored at the temperature of ca. $20^{\circ} \mathrm{C}$, a decrease of about $78 \%$ was observed. A significant decrease in HMF content (about 33\%) was found already after 9 months of storage. 


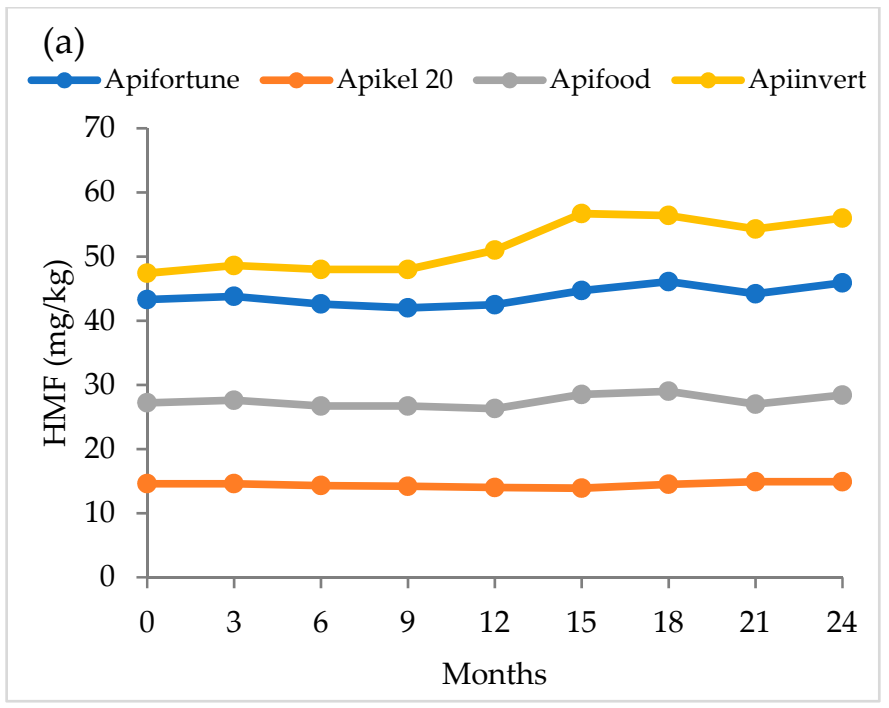

(b)

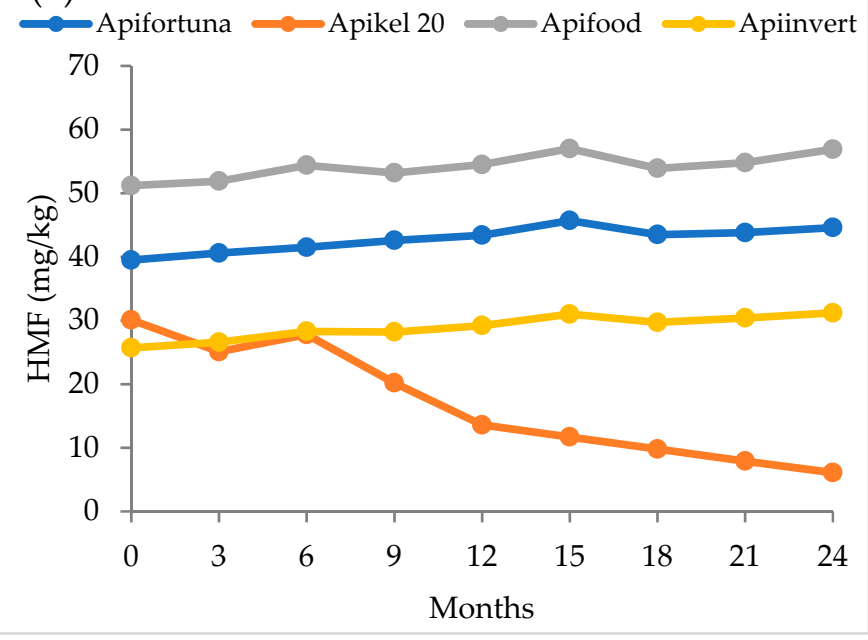

Figure 2. Changes of HMF content in syrups during storage at 10-14 ${ }^{\circ} \mathrm{C}$ (a) from 2012 and (b) from 2013.

Storage at the temperature of ca. $4{ }^{\circ} \mathrm{C}$ resulted in an increase in HMF content in starch syrups (Apifortune, Apifood) and the inverted saccharose syrup (Apiinvert) from both years not exceeding $10 \%$ after 24 months of storage (Figure 3). Again, the starch syrup Apikel 20 was an exception because, similarly to the temperatures of $20^{\circ} \mathrm{C}$ and $10-14{ }^{\circ} \mathrm{C}$, a decrease in HMF content of about $78 \%$ was found in syrups purchased in both years.

(a)

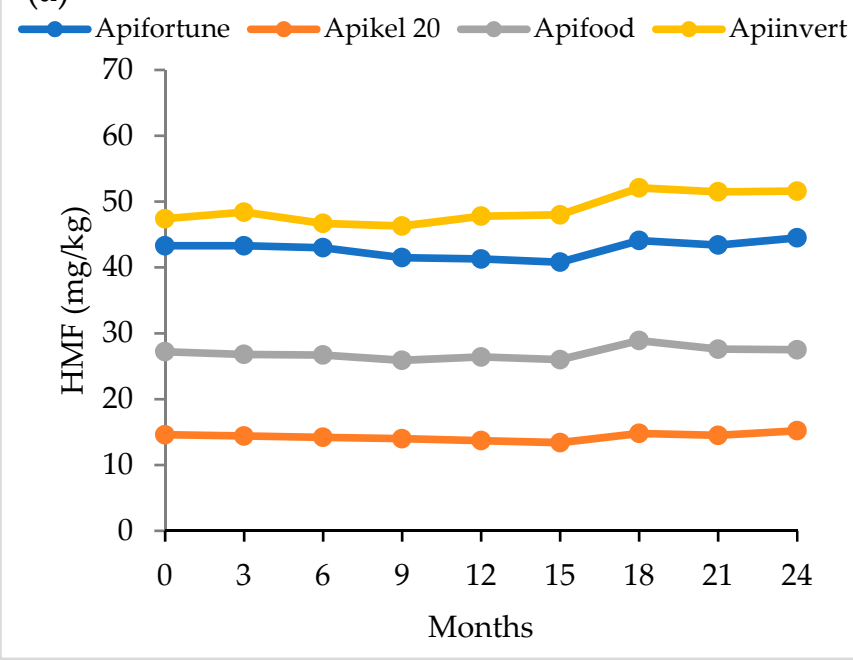

(b)
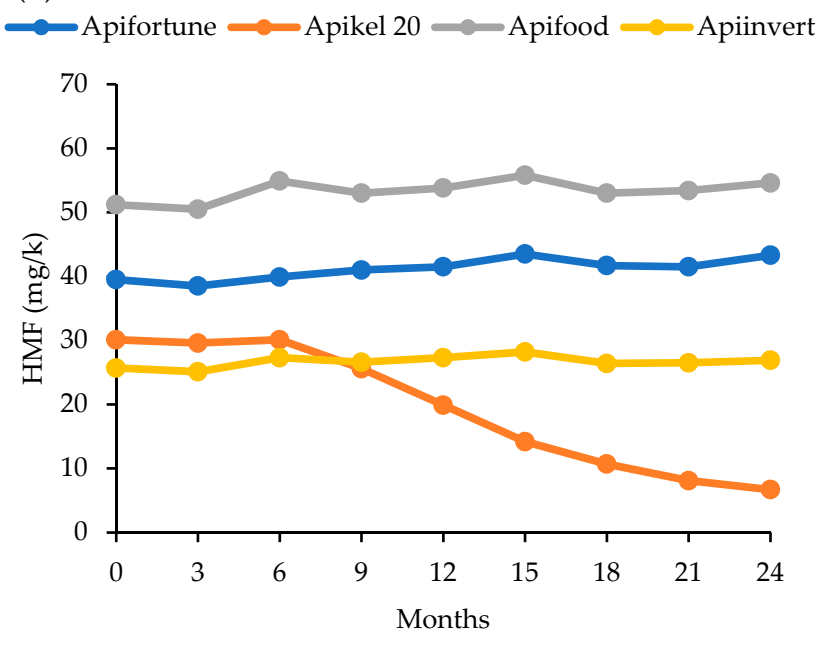

Figure 3. Changes of HMF content in syrups during storage at about $4{ }^{\circ} \mathrm{C}$ (a) from 2012 and (b) from 2013.

Fructose and glucose contents in starch and inverted saccharose syrups did not change significantly in comparison to fresh syrups even after 24 months of storage (Figures 4-9). Only a slight increase in the content of fructose and glucose was observed in the inverted saccharose syrup stored at ca. $20^{\circ} \mathrm{C}$ and at $10-14{ }^{\circ} \mathrm{C}$ (Figures 4, 5, 7 and 8). 
(a)

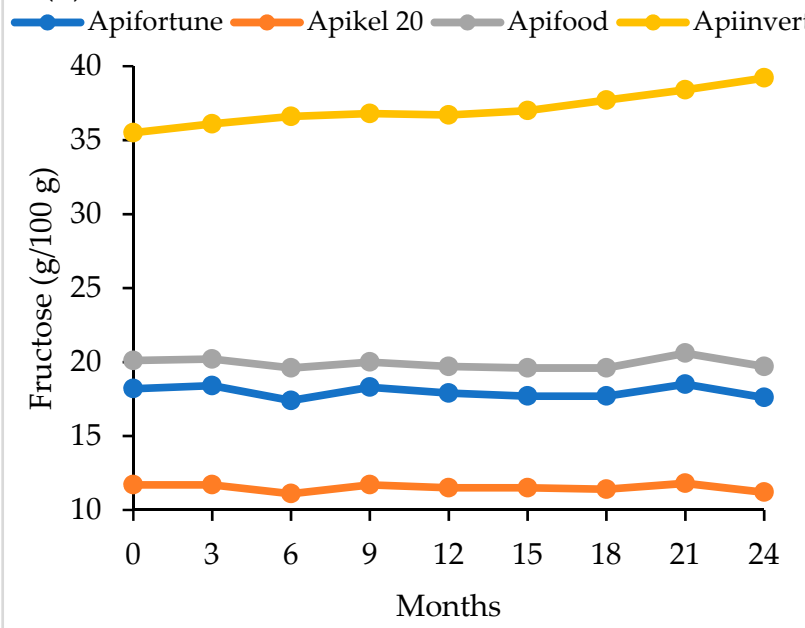

(b)

$\longrightarrow$ Apifortune $\longrightarrow$ Apikel $20 \longrightarrow$ Apifood $\longrightarrow$ Apiinvert

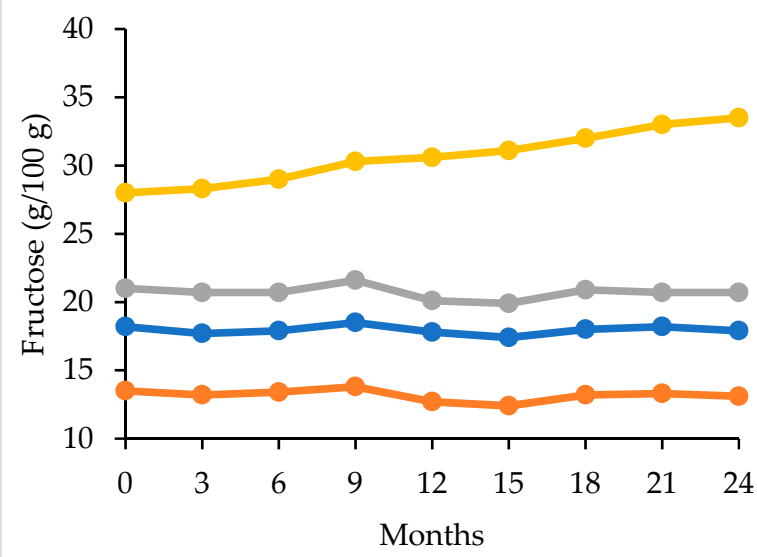

Figure 4. Changes of fructose content in syrups during storage at about $20^{\circ} \mathrm{C}$ (a) from 2012 and (b) from 2013.

(a)

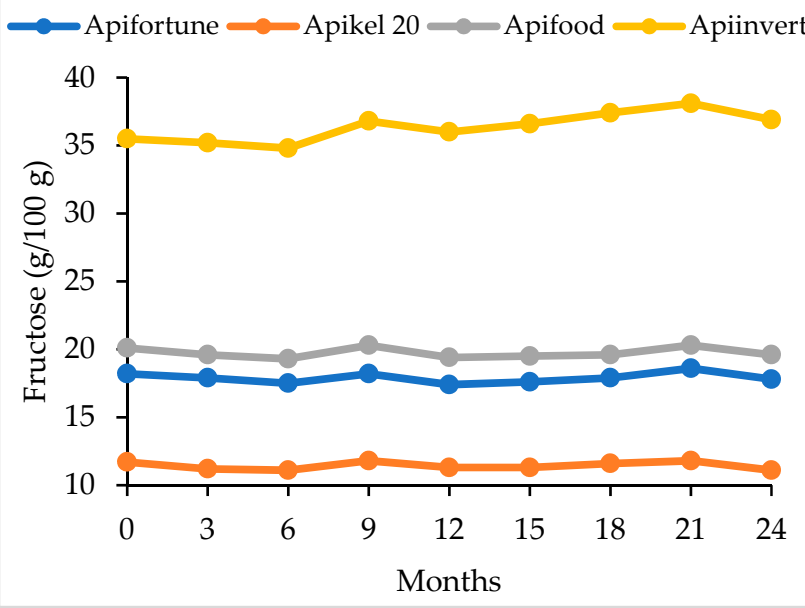

(b)

$\longrightarrow$ Apifortuna $\longrightarrow$ Apikel $20 \longrightarrow$ Apifood $\longrightarrow$ Apiinver

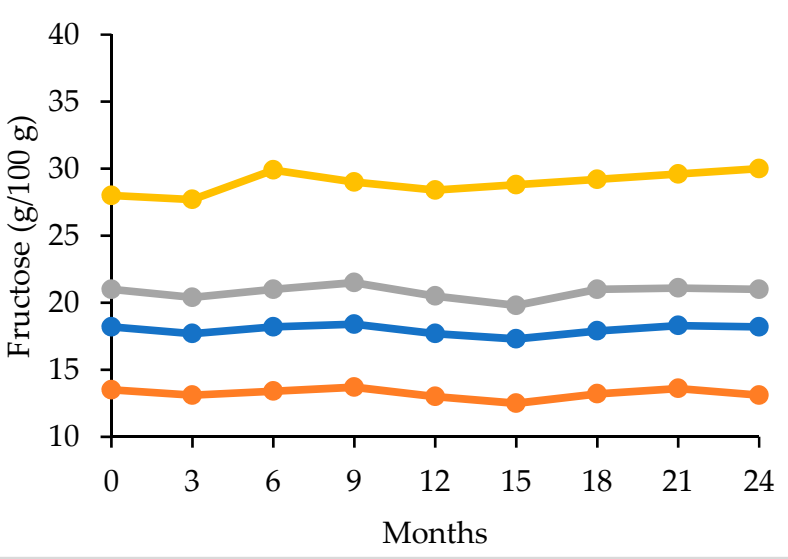

Figure 5. Changes of fructose content in syrups during storage at 10-14 ${ }^{\circ} \mathrm{C}$ (a) from 2012 and (b) from 2013.

(a)

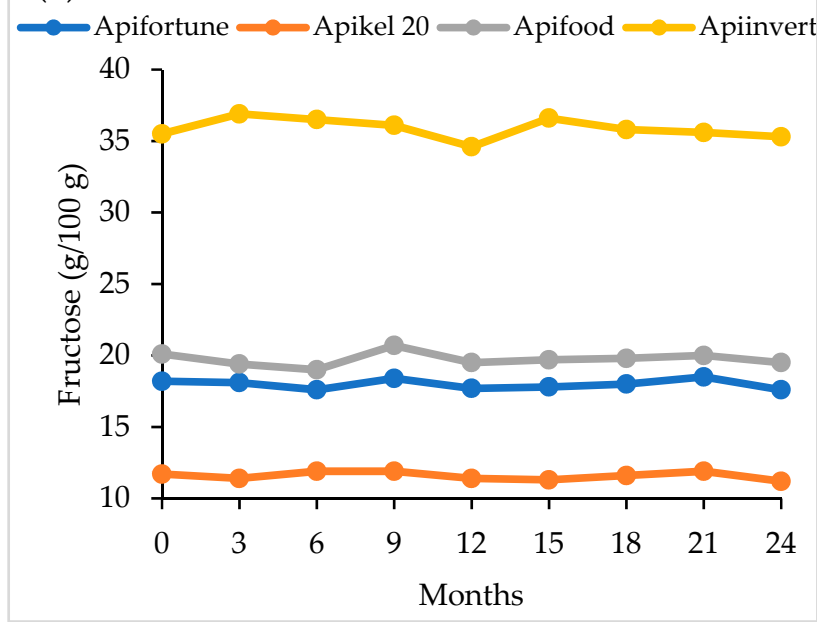

(b)

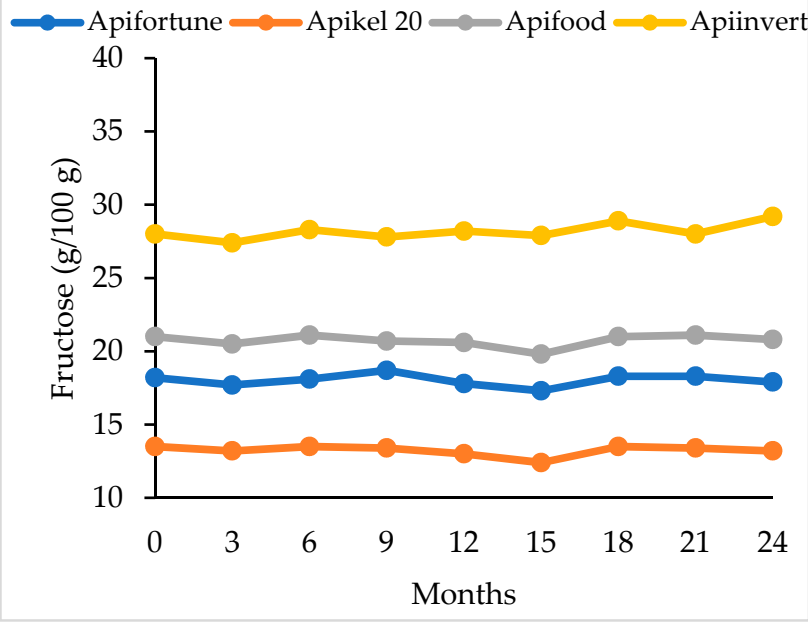

Figure 6. Changes of fructose content in syrups during storage at about $4{ }^{\circ} \mathrm{C}$ (a) from 2012 and (b) from 2013. 
(a)

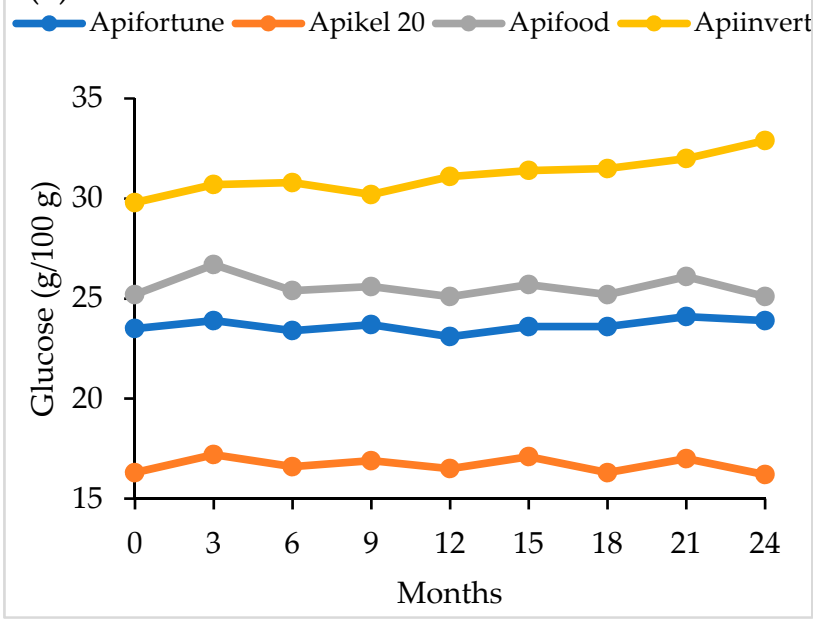

(b)

$\longrightarrow$ Apifortune $\longrightarrow$ Apikel $20 \longrightarrow$ Apifood $\longrightarrow$ Apiinvert

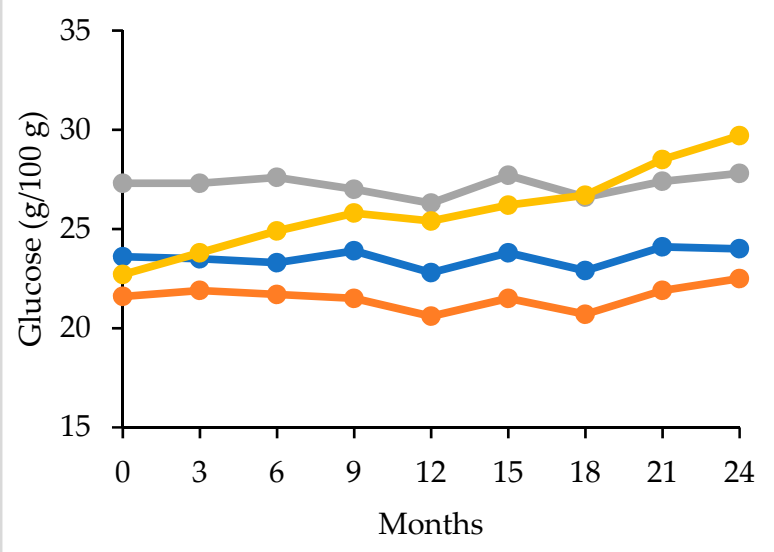

Figure 7. Changes of glucose content in syrups during storage at about $20^{\circ} \mathrm{C}$ (a) from 2012 and (b) from 2013.

(a)

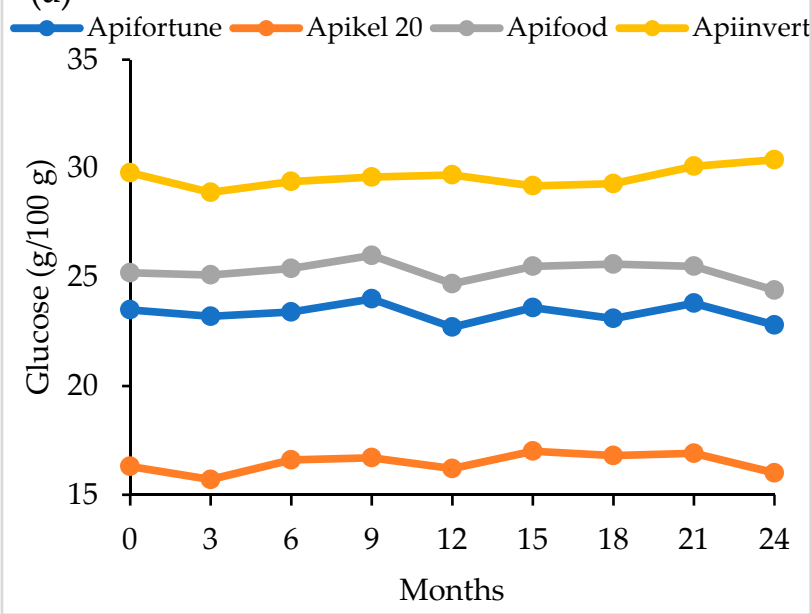

(b)

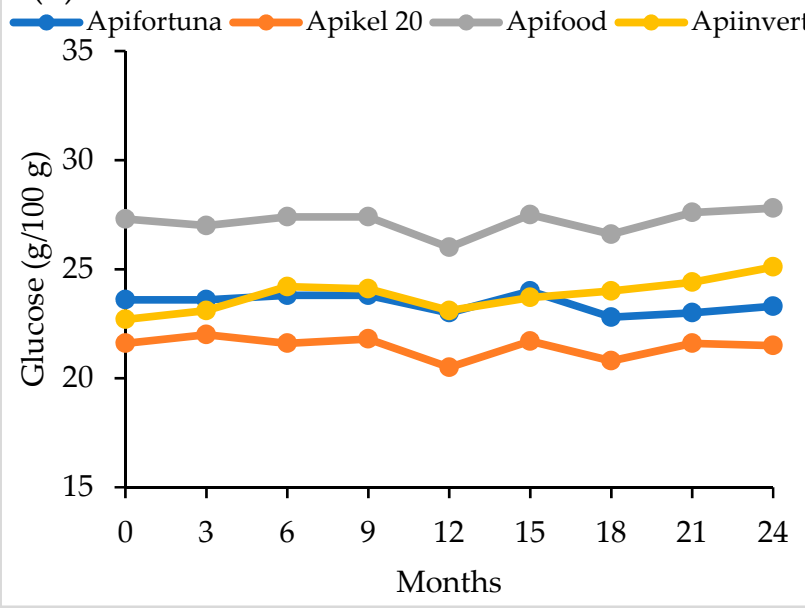

Figure 8. Changes of glucose content in syrups during storage at 10-14 ${ }^{\circ} \mathrm{C}$ (a) from 2012 and (b) from 2013.

(a)

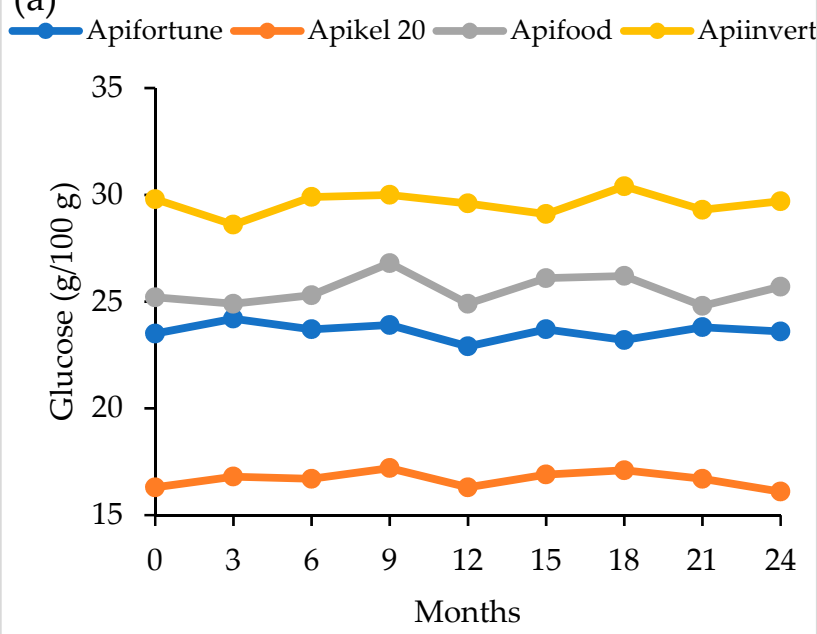

(b)

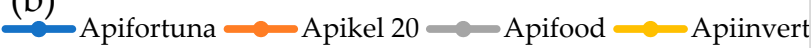

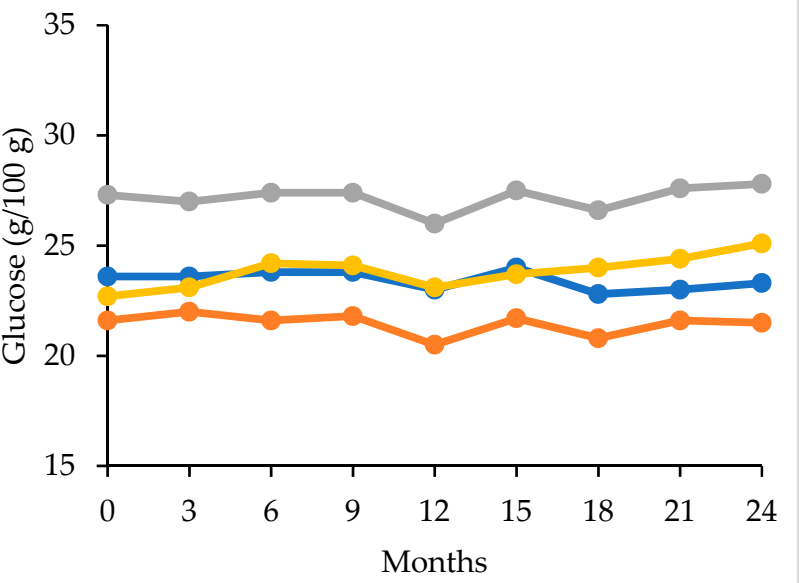

Figure 9. Changes of glucose content in syrups during storage at about $4{ }^{\circ} \mathrm{C}$ (a) from 2012 and (b) from 2013. 
No changes in the ratio of fructose to glucose content in starch syrups and inverted saccharose syrup during storage were found. The values of this parameter for stored syrups were on the same level as fresh syrups (Table 1). Saccharose content in inverted saccharose syrup decreased during storage at different temperatures, and the highest decrease of this disaccharide occurred at ca. $20{ }^{\circ} \mathrm{C}$ (Figure 10). At this temperature, saccharose content decreased by $70 \%$ (after 12 months) and $88 \%$ (after 24 months) in the syrup purchased in 2012 and 26\% (after 12 months) and 60\% (after 24 months) in the syrup from 2013. At lower temperatures $\left(10-14{ }^{\circ} \mathrm{C}\right.$ and ca. $\left.4{ }^{\circ} \mathrm{C}\right)$, the saccharose breakdown to simple sugars was much slower.
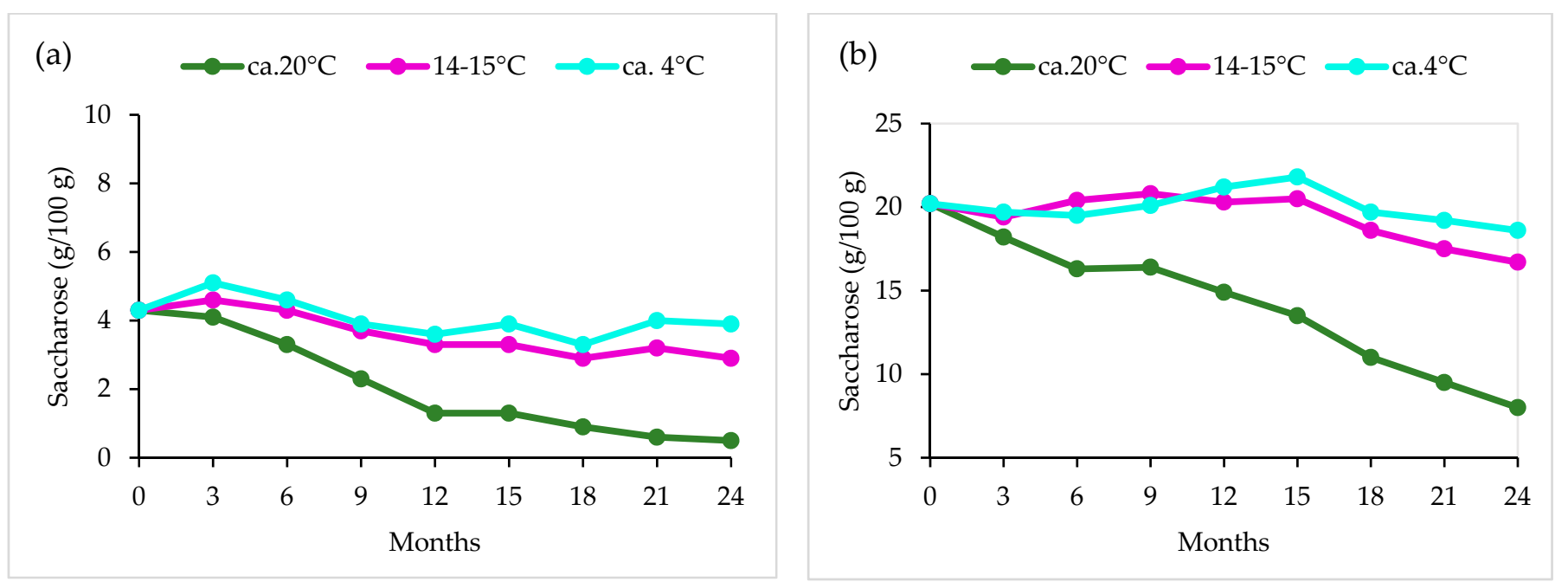

Figure 10. Changes of saccharose content in inverted saccharose syrup (Apiinvert) during storage (a) from 2012 and (b) from 2013.

In starch syrups, small differences in the contents of maltose and maltotriose between fresh and stored syrups were found (Figures 11-16), whereas no differences in the contents of maltodextrins between fresh and stored starch syrups were noticed. Even after 24 months of storage at all the tested temperatures (ca. $20^{\circ} \mathrm{C}, 10-14^{\circ} \mathrm{C}$, and ca. $4^{\circ} \mathrm{C}$ ), the maltodextrins content in starch syrups was at the same level as fresh syrups (Table 1).
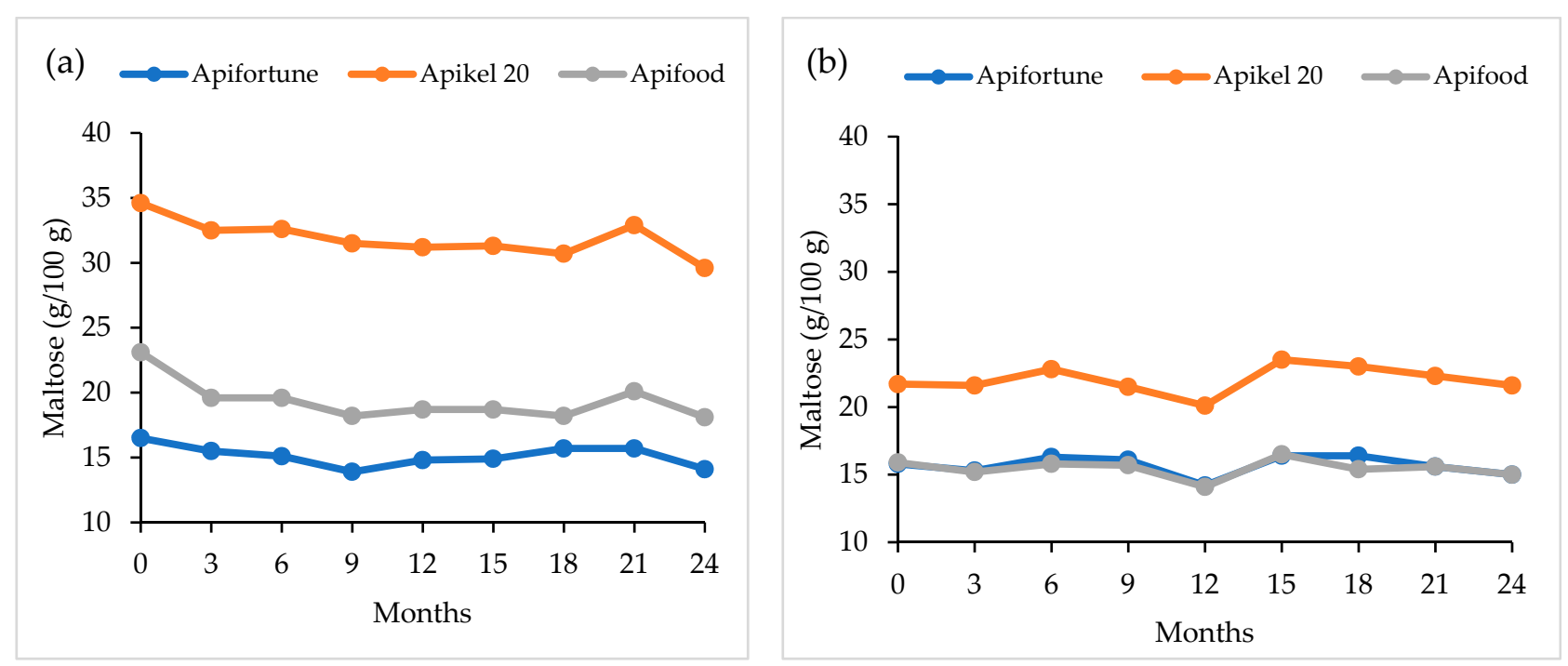

Figure 11. Changes of maltose content in syrups during storage at about $20^{\circ} \mathrm{C}$ (a) from 2012 and (b) from 2013. 

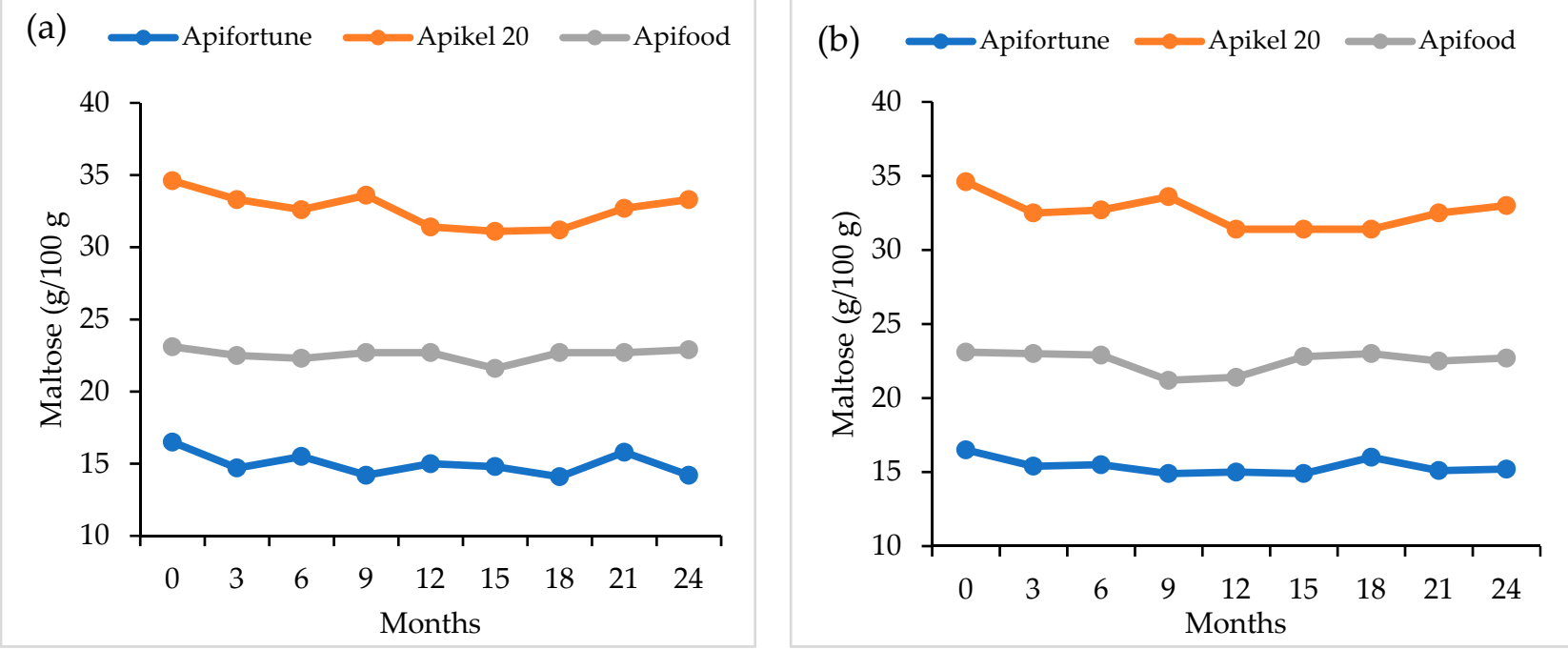

Figure 12. Changes of maltose content in syrups during storage at 10-14 ${ }^{\circ} \mathrm{C}$ (a) from 2012 and (b) from 2013.

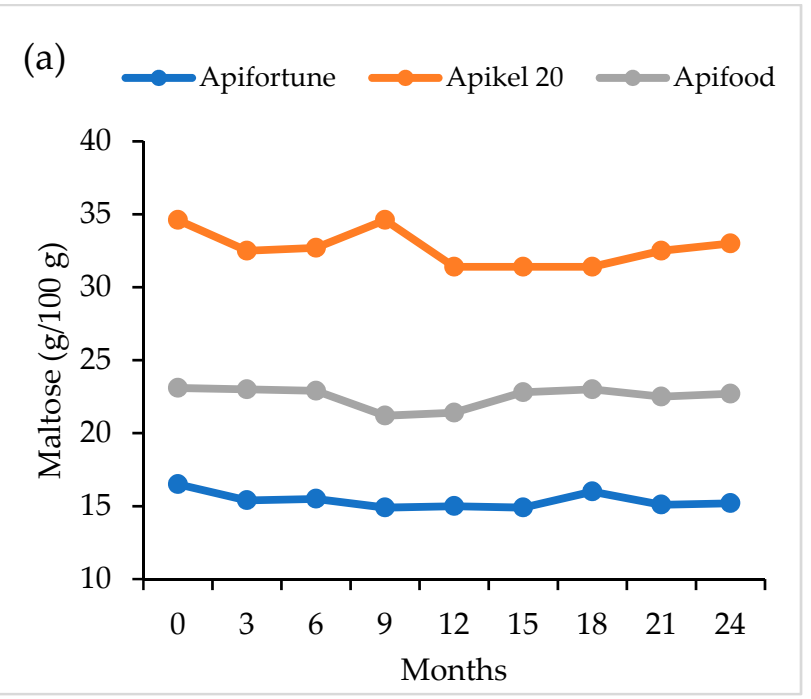

(b) $\rightarrow$ Apifortune $\longrightarrow$ Apikel $20 \multimap$ Apifood

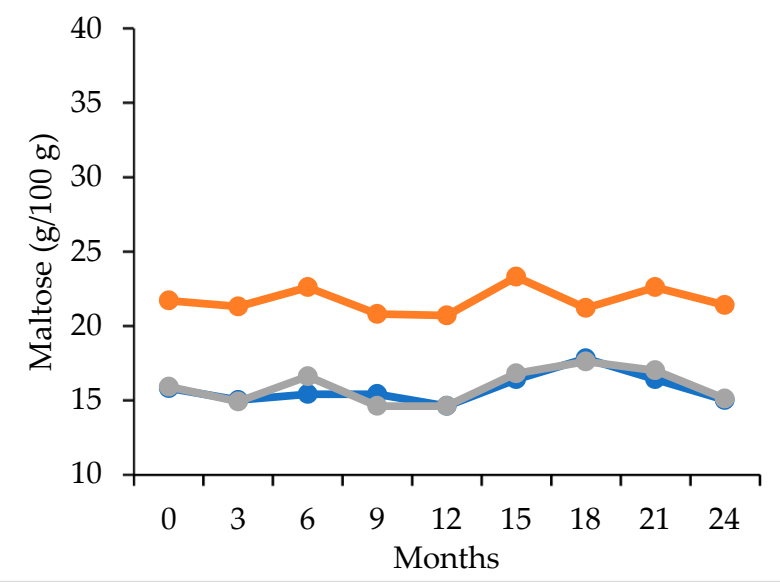

Figure 13. Changes of maltose content in syrups during storage at about $4{ }^{\circ} \mathrm{C}$ (a) from 2012 and (b) from 2013.

(a) $\longrightarrow$ Apifortune $\longrightarrow$ Apikel $20 \longrightarrow$ Apifood

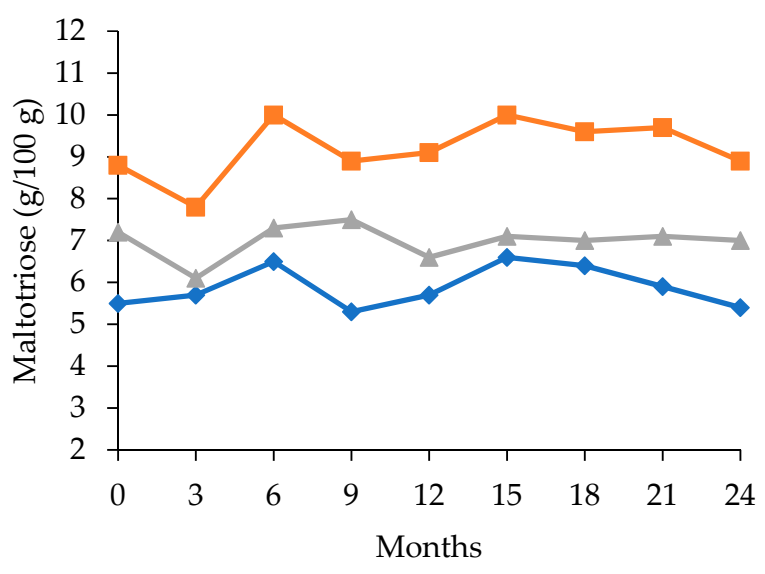

(b) $\multimap$ Apifortune $\longrightarrow$ Apikel $20 \multimap$ Apifood

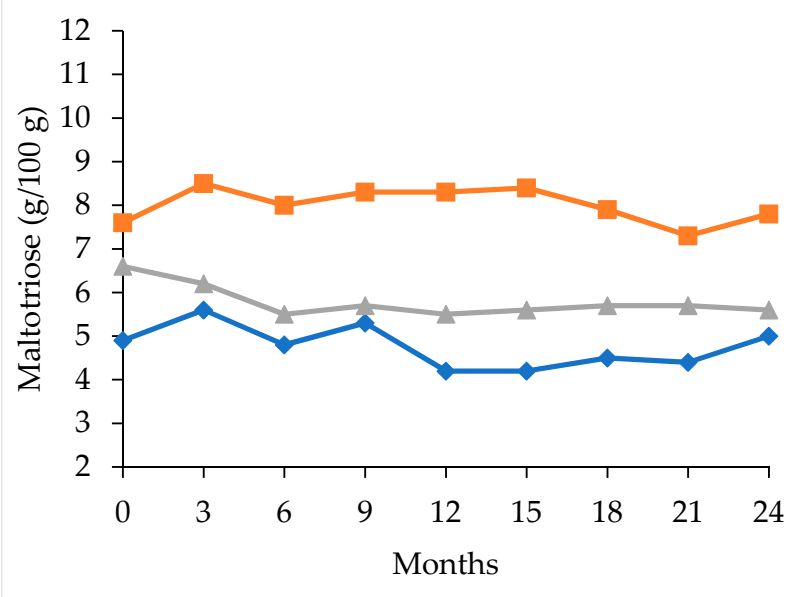

Figure 14. Changes of maltotriose content in syrups during storage at about $20^{\circ} \mathrm{C}$ (a) from 2012 and (b) from 2013. 

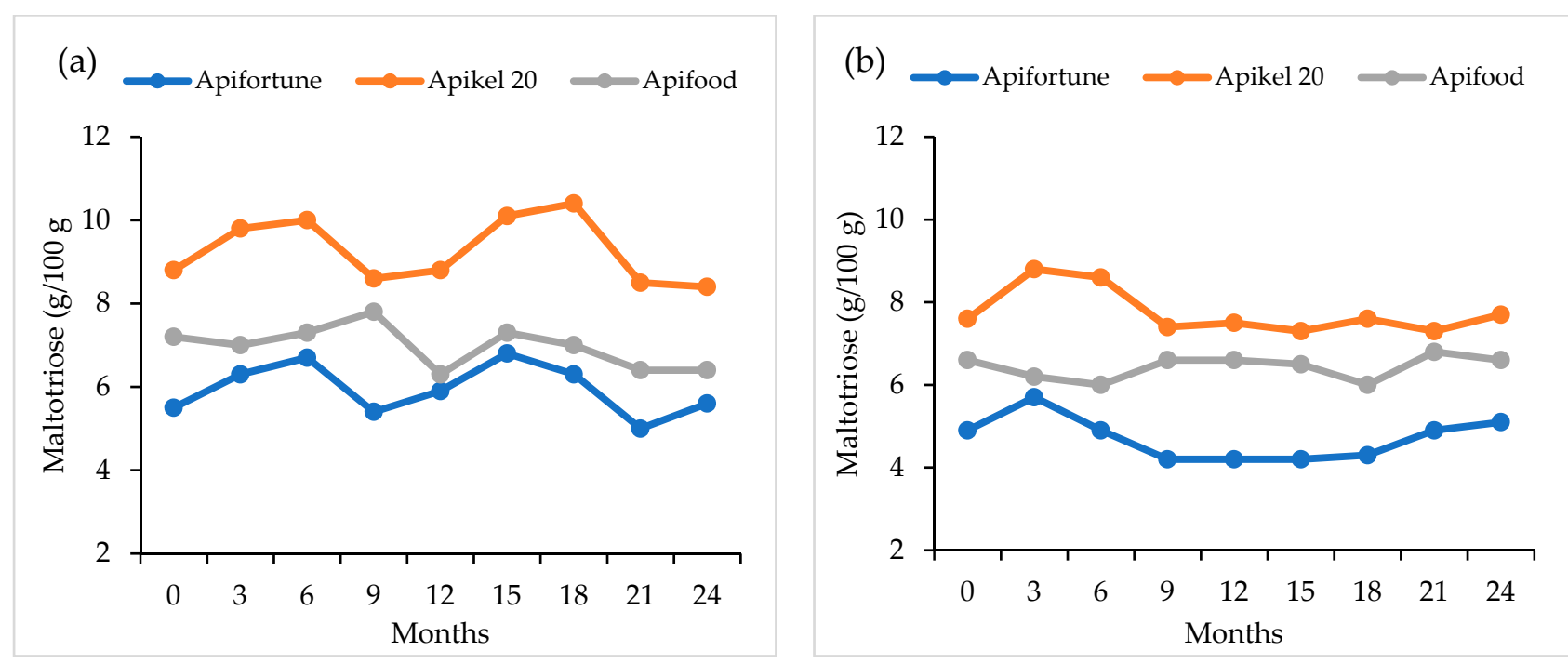

Figure 15. Changes of maltotriose content in syrups during storage at 10-14 ${ }^{\circ} \mathrm{C}$ (a) from 2012 and (b) from 2013.
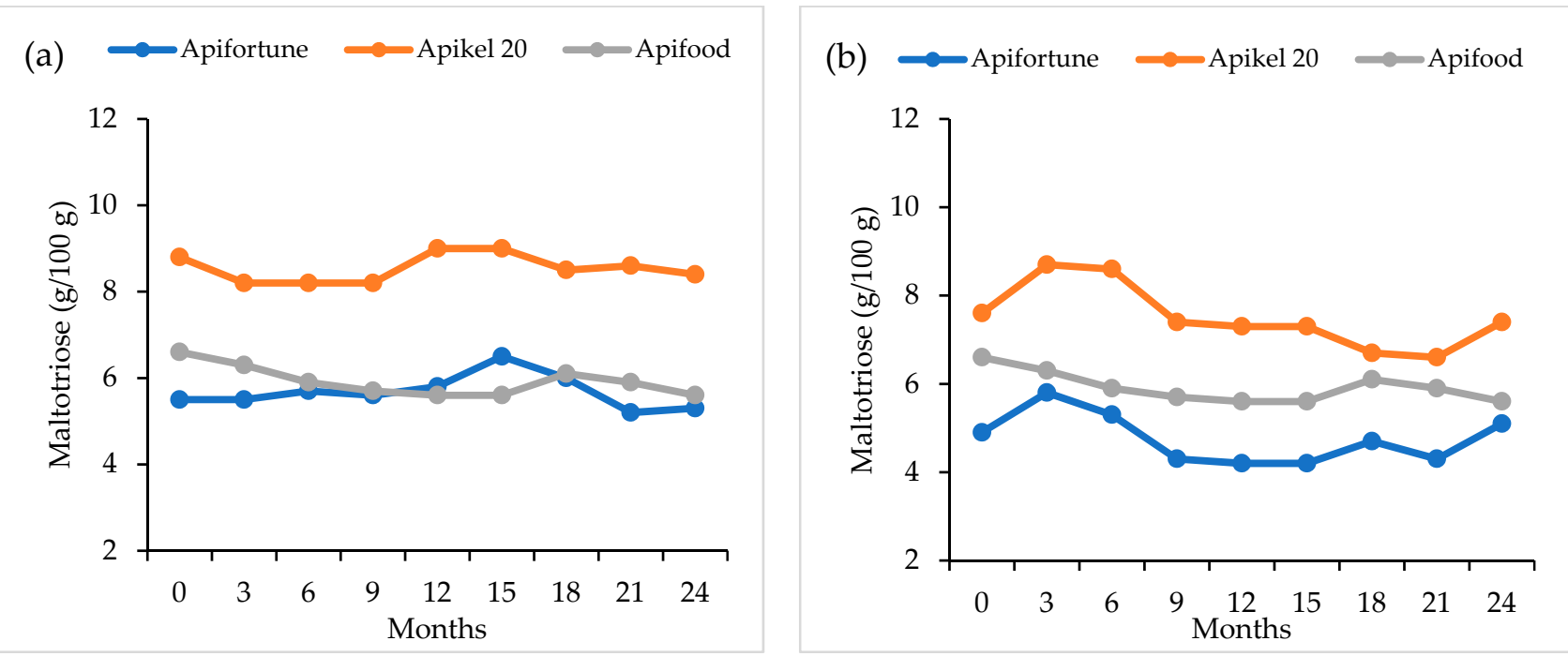

Figure 16. Changes of maltotriose content in syrups during storage at about $4{ }^{\circ} \mathrm{C}$ (a) from 2012 and (b) from 2013.

In syrups purchased in 2012, $\mathrm{pH}$ changes during storage at different temperatures was similar in the starch syrups, whereas in the inverted saccharose syrup, only slight changes of this parameter were found (Figures 17-19). In syrups purchased in 2013, the changes of this parameter at all of the tested temperatures were similar in all types of syrups. The $\mathrm{pH}$ value of starch syrups purchased in 2012 and stored up to 12 months at ca. $20{ }^{\circ} \mathrm{C}$ was similar to the value found in fresh syrups, whereas after 24 months of storage, the value of this parameter was slightly lower (Figure 17a). In the case of starch syrups and the inverted saccharose syrup purchased in 2013, a significant decrease in the $\mathrm{pH}$ was found during first 6 months of storage at $20^{\circ} \mathrm{C}$ (Figure 17b). During the next months, fluctuations of this parameter were found. After 24 months, the $\mathrm{pH}$ was lower in comparison to fresh syrups stored for 12 months and, on average, amounted to 4.00 (starch syrups). At lower temperatures $\left(10-14{ }^{\circ} \mathrm{C}\right.$ and ca. $\left.4{ }^{\circ} \mathrm{C}\right)$, changes in $\mathrm{pH}$ values were slower (Figures 18 and 19). 


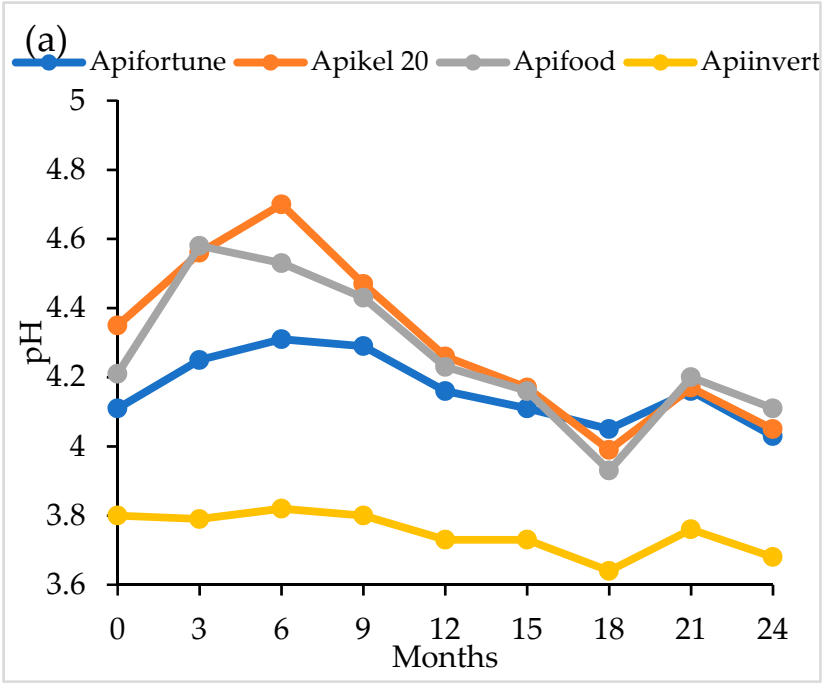

(b) Apifortune $\longrightarrow$ Apikel $20 \longrightarrow$ Apifood $\longrightarrow$ Apiinvert

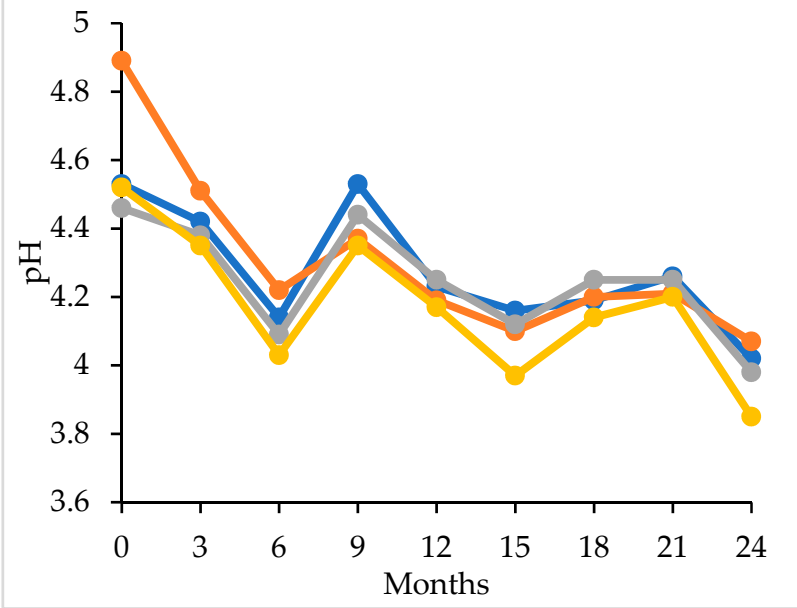

Figure 17. Changes of $\mathrm{pH}$ of syrups during storage at ca. $20^{\circ} \mathrm{C}$ (a) from 2012 and (b) from 2013.

(a)

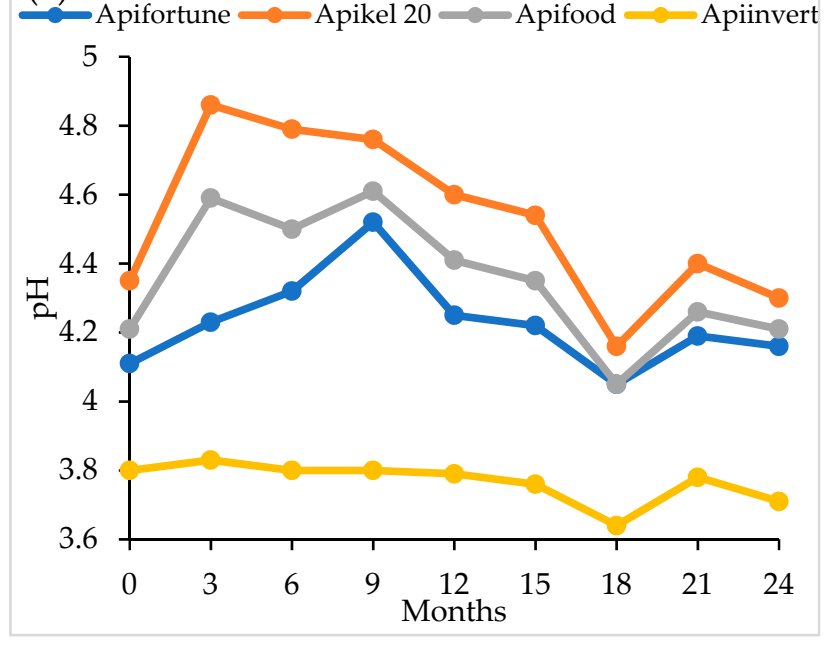

(b)

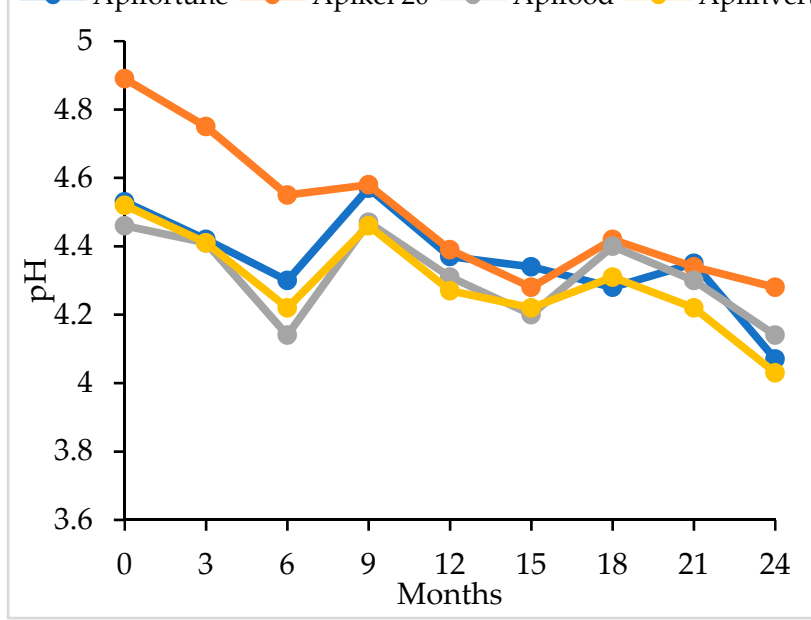

Figure 18. Changes of $\mathrm{pH}$ of syrups during storage at $10-14{ }^{\circ} \mathrm{C}$ (a) from 2012 and (b) from 2013.

(a)

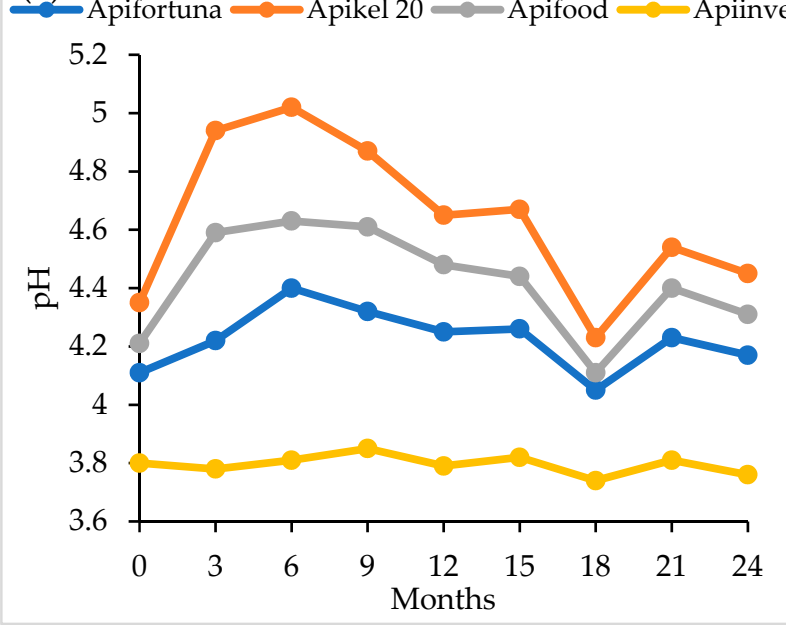

(b)

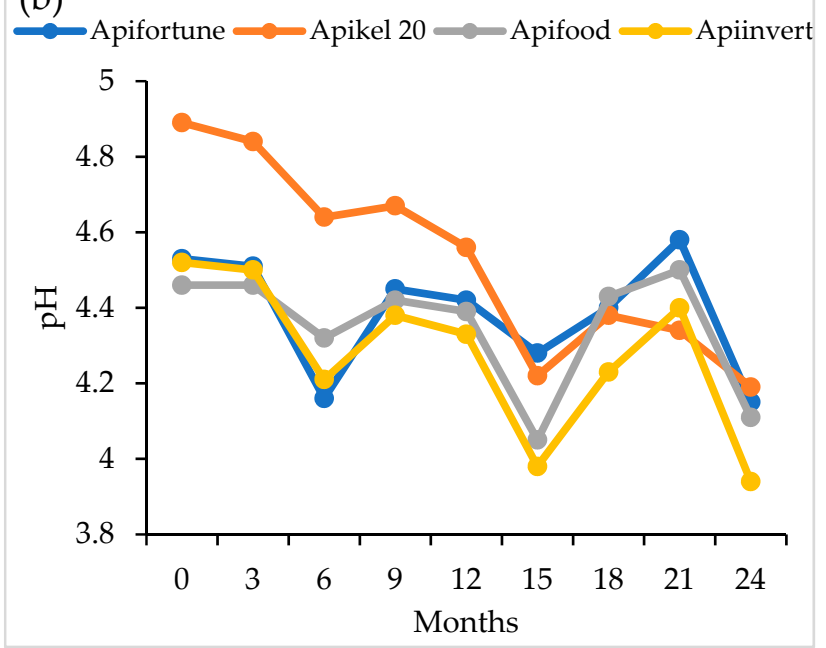

Figure 19. Changes of $\mathrm{pH}$ of syrups during storage at ca. $4{ }^{\circ} \mathrm{C}$ (a) from 2012 and (b) from 2013. 
Free acidity of fresh starch syrups purchased in 2012 and 2013, respectively, was $4.8 \mathrm{mval} / \mathrm{kg}$ and $1.2 \mathrm{mval} / \mathrm{kg}$ on average (Table 1 ). Free acidity of the inverted saccharose syrup (Apiinvert) amounted to $5.9 \mathrm{mval} / \mathrm{kg}$ and $0.9 \mathrm{mval} / \mathrm{kg}$, respectively. In starch syrups and the inverted saccharose syrup purchased in 2012 stored at three different temperatures (ca. $20^{\circ} \mathrm{C}, 10-14{ }^{\circ} \mathrm{C}$, and ca. $4{ }^{\circ} \mathrm{C}$ ), a slight decrease was observed. In the syrups purchased in 2013, a slight increase in the free acidity was found. However, free acidity of stored syrups oscillated around the values determined in fresh syrups.

Electrical conductivity of fresh starch syrups and the inverted saccharose syrup was very low $(0.01-0.05 \mathrm{mS} / \mathrm{cm}$ ) (Table 1$)$ and did not change during storage. After 24 months, the value of this parameter was at the similar level as fresh syrups and, in all cases, did not exceed $0.05 \mathrm{mS} / \mathrm{cm}$. In addition, no changes in water content during storage in the experimental conditions were found in all the tested starch syrups and the inverted saccharose syrup. Water content amounted to $20-23 \%$ in starch syrups and $26-27 \%$ in the inverted saccharose syrup (Table 1).

\section{Discussion}

There are no reliable literature data on changes in the physicochemical parameters of analyzed syrups during storage under different conditions. So far, conducted studies on the changes in chemical composition during storage in different conditions (temperature, time) have mainly concerned honey, which is a natural carbohydrate food for bees. Therefore, the products intended for the winter feeding of bees (being an alternative to honey) should have comparable sugar composition and other physicochemical properties such as $\mathrm{pH}$ and acidity. These products should also have a low content of HMF, which can be a potential threat to honeybees. It can be assumed that biochemical changes, especially concerning HMF content in starch syrups during storage, are similar to honey. Our studies showed that the changes in chemical composition of starch syrups and the inverted saccharose syrup during storage in different conditions mainly involved the HMF content. This compound forms in products with high content of simple sugars (fructose and glucose) such as honey during heating at the stage of decrystallization and during storage. The rate of HMF formation is mainly a function of temperature and time [18,19,31,32]. The abovementioned authors have indicated that, on the one hand, analyzing HMF in food products is used to monitor changes occurring during heating, while on the other hand, HMF is treated as a compound unwanted in foods due to its toxic, mutagenic, and cancerogenic properties.

Many authors have suggested a toxic effect of HMF on bees [9,13,22-24,26,27]. Consequently, monitoring HMF content in products used for the winter feeding of bees is very important and extremely necessary.

The syrups used in our study were stored at three different temperatures: ca. $20^{\circ} \mathrm{C}$, $10-14{ }^{\circ} \mathrm{C}$, and ca. $4{ }^{\circ} \mathrm{C}$, and physicochemical parameters were measured after $3,6,9,12,15$, 18,21 , and 24 months of storage at these temperatures. HMF content in two starch syrups (Apifortune, Apifood) and the inverted saccharose syrup (Apiinvert) increased during storage at all the experimental temperatures, with the highest increase at the temperature of ca. $20^{\circ} \mathrm{C}$. At the lower temperatures $\left(10-14{ }^{\circ} \mathrm{C}\right.$ and ca. $\left.4{ }^{\circ} \mathrm{C}\right)$, the $\mathrm{HMF}$ formation was much slower. The results of our study support the studies of other authors dealing with the issue of the influence of different factors (temperature, duration) at the stage of heating and storing honey on HMF formation [16-18,31,32]. These authors have reported that HMF already forms in low temperatures at acidic $\mathrm{pH}$. However, high temperature and long storage time cause a significant increase in this compound's concentrations. It needs to be emphasized that the syrups included in our study had acidic $\mathrm{pH}$, which is indicated by other authors as one of the main factors facilitating HMF formation in honey next to temperature and time. In our studies, the starch syrup Apikel 20 was an exception. The HMF content in this syrup increased only slightly in the syrup purchased in 2012, and in the syrup from 2013, it even significantly decreased already after 9 months of storage at all the experimental temperatures. The decrease in HMF content during storage was previously observed in some honey varieties (citrus, chestnut, buckwheat, phacelia, and 
multifloral) $[16,29,31,32]$. Authors have explained this phenomenon, although very generally, with the intensification of the HMF degradation processes with the simultaneous slowdown of HMF formation processes. Literature data indicate that the HMF formation during storage is correlated with the chemical characteristics ( $\mathrm{pH}$, acidity) of the different kinds of honey $[29,31]$. Our studies showed that, compared to other starch syrups, Apikel 20 purchased in 2013 had higher $\mathrm{pH}$, which could affect the kinetics of HMF formation in this syrup. Our research should be considered as preliminary research. Kinetics trials should be extended to more syrups samples to verify the behavior of the formation and degradation of HMF and to establish shelf life for starch products recommended as winter food for bees. Due to complexity of the processes of HMF formation during heating treatment and storage, it is difficult to establish the acceptable concentration of this compound in syrups recommended for winter feeding of bees, and thus, the shelf life of these products. In order to establish shelf life for food products, some authors have attempted to develop and use mathematic models. However, these models require extensive studies, including the study of as many factors as possible that might have significant influence on the HMF formation $[9,18,28,31,32]$. In the case of our studies, at the stage of planning the experiment, too few factors were included, e.g., not very precise storage temperature. As a result, no model described by the abovementioned authors could have been used.

Some authors have reported that fructose is more reactive at the stage of HMF formation in comparison to glucose $[18,20]$. Relative reactivity of saccharose, glucose, and fructose in formation of HMF has been experimentally established in environments with a $\mathrm{pH}$ of 3.5 [20]. In such conditions, the relative reactivity of fructose was about 30 , and saccharose was 20-times more reactive than glucose. Using these dependences, we were able to explain why the HMF formation rate found in the inverted saccharose syrup was higher in comparison to the starch syrups. In our studies, the fructose content in the inverted syrup was much higher that the glucose content $(F / G=1.2$, on average) in comparison to starch syrups where this relation was reversed $(F / G=0.74$, on average) (Table 1$)$. The inverted syrup contained relatively high amounts of fructose and saccharose, showing, as reported by Lee and Nagy [20], higher relative reactivity in comparison to glucose. The high content of fructose and saccharose could be a factor contributing to the formation of HMF in the tested syrups during storage, especially in inverted saccharose syrup. It needs to be mentioned, however, that glucose forms oligosaccharides containing reactive-reducing groups, which create a higher risk of cross-polymerization with reactive intermediates, including HMF [18].

According to the requirements of the Codex Alimentarius Commission (CODEX STAN 12-1981 [45] and the EU Directive [46], the maximal HMF content in honey should not exceed $40 \mathrm{mg} / \mathrm{kg}$, except tropical honeys, for which both documents allow higher content of this compound (up to $80 \mathrm{mg} / \mathrm{kg}$ ). Initial HMF content in the starch syrups and the inverted saccharose syrup included in our study ranged from $14.6 \mathrm{mg} / \mathrm{kg}$ to $51.2 \mathrm{mg} / \mathrm{kg}$. During their storage at the experimental temperatures (ca. $20^{\circ} \mathrm{C}, 10-14{ }^{\circ} \mathrm{C}$, and ca. $4{ }^{\circ} \mathrm{C}$ ), HMF content, especially at the temperature of ca. $20^{\circ} \mathrm{C}$, quickly increased. After 12 months of storage, HMF content exceeded $50 \mathrm{mg} / \mathrm{kg}$ in the majority of syrups. According to our earlier studies, HMF content of up to $50 \mathrm{mg} / \mathrm{kg}$ had no negative influence on the wintering and spring development of bee colonies [11,43]. In one of the starch syrups included in our experiment, the HMF content decreased. Properties of the main HMF metabolites (HMFA-5-hydroxymethylfurfuroic acid, SMF-5-silfoxymethylfurfuralu) are not yet well recognized. In vivo studies in this field are incomplete and controversial. HMF shows mutagenic activity and damages DNA helix structure [47]. HMF metabolites (HMFA, SMF) have cytotoxic, genotoxic, neurotoxic, mutagenic, and cancerogenic properties and might cause cancerous lesions in tissues of the liver, skin, and lower parts of the colon [47,48]. It needs to be stressed, however, that the lack of comprehensive studies on the toxicological effects of exposing human organisms to HMF makes it impossible to establish an acceptable daily intake of HMF for humans. This refers to bees as well. However, the mechanism of the toxic influence of HMF and its derivatives on bees is not yet fully known. Changes in 
sugar composition (fructose, glucose, maltose, maltotriose, and starch dextrins) in starch syrups during storage at different temperatures were not significant enough to have any influence on the quality of the winter food even after 24 months of storage at the analyzed temperatures. Our earlier studies have shown that sugar composition determined in the same starch syrups ensures safe wintering and dynamic spring development of bees [11,43].

Hydrolysis of saccharose in the inverted saccharose syrup during storage was different than in the homemade saccharose syrup which was prepared from beat sugar (sugar to water ratio 5:3) stored in the same conditions [49]. After 3 months of storing the saccharose syrup at the temperature of only ca. $4{ }^{\circ} \mathrm{C}$, the breakdown of saccharose through the intermediate, the trisaccharide erlose, occurred. We did not find erlose (at the limit of detection of $0.2 \mathrm{~g} / 100 \mathrm{~g}$ ) in the inverted saccharose syrup stored at the same temperature. It needs to be emphasized that $\mathrm{pH}$ of the saccharose syrup (home-made) was alkaline (7.67), while the inverted saccharose syrup's $\mathrm{pH}$ was acidic (3.80 and 4.52). Hydrogen ions act as a catalyst of the reaction of saccharose hydrolysis to simple sugars, fructose, and glucose, which probably occurred in the case of the inverted saccharose syrup included in our experiment. However, saccharose hydrolysis to simple sugars through the trisaccharide, erlose, occurred at the initial stage in the alkaline environment, which could have had a significant influence on the process of the breakdown of this disaccharide.

In conclusion, the changes in chemical composition of starch syrups and the inverted saccharose syrup, mainly the HMF content, depended on syrup's type and storage conditions (temperature, time). Starch syrups analyzed in our study stored at the temperature of ca. $20^{\circ} \mathrm{C}$ maintained their unchanged physicochemical properties for up to 6 months. At lower temperatures $\left(10-14^{\circ} \mathrm{C}\right.$ and ca. $\left.4{ }^{\circ} \mathrm{C}\right)$, the analyzed syrups maintained their properties for a longer time (for about 1 year). Storing these syrups at higher temperatures (ca. $20^{\circ} \mathrm{C}$ ) led to decreased $\mathrm{pH}$ and increased HMF content, a compound which has not yet been sufficiently investigated regarding its influence on bees. Therefore, the shelf life of the tested syrups intended for the winter feeding of bees stored at the temperature of ca. $20{ }^{\circ} \mathrm{C}$ should not exceed 6 months, and at lower temperatures $\left(10-14{ }^{\circ} \mathrm{C}\right.$ and ca. $\left.4{ }^{\circ} \mathrm{C}\right)$, it should not exceed 12 months.

Author Contributions: Conceptualization and methodology, T.S., E.W., P.S. (Piotr Semkiw), and P.S. (Piotr Skubida); investigation, P.S. (Piotr Semkiw), P.S. (Piotr Skubida), T.S., E.W., K.J., and M.W.; writing-original draft preparation, T.S. and E.W.; writing-review and editing, T.S., E.W., P.S. (Piotr Semkiw), P.S. (Piotr Skubida), K.J., and M.W.; visualization, T.S., E.W., and P.S. (Piotr Semkiw); supervision, T.S. All authors have read and agreed to the published version of the manuscript.

Funding: This research received no external funding.

Institutional Review Board Statement: Not applicable.

Informed Consent Statement: Not applicable.

Data Availability Statement: Not applicable.

Conflicts of Interest: The authors declare no conflict of interest.

\section{References}

1. Ohe von der, W.; Schönberger, H. Für die Ernährung der Bienen: Futtersirup im Vergleich. Dtsch. Bienen J. 2000, 8, 312-314.

2. Ohe von der, W.; Schönberger, H. Bienenernährung: Futtersirup im Vergleich. Bienenvater 2002, 123, 11-15.

3. Liebig, G. Getreidestärkesirup: Besser als sein Ruf. Dtsch. Bienen J. 2005, 13, 18-19.

4. Rybak-Chmielewska, H.; Konopacka, Z. Co to jest izoglukoza? Pszczelarstwo 2005, 6, 6-7.

5. Ceksteryte, V.; Racys, J. The quality of syrups used for bee feeding before winter and their suitability for bee wintering. J. Apic. Sci. 2006, 50, 5-14. [CrossRef]

6. Rybak-Chmielewska, H.; Szczęsna, T.; Bieńkowska, M. Gas chromatograph (GC) study of sugar composition in honeys and winter stores processed by bees from sucrose syrups. J. Apic. Sci. 2006, 50, 147-155.

7. Rybak-Chmielewska, H.; Szczęsna, T.; Waś, E. Attempt to assay maltodextrins occurring in starch syrup and in winter stores made by bees from that syrup. J. Apic. Sci. 2006, 50, 127-135.

8. Rybak-Chmielewska, H. High performance liquid chromatography (HPLC) study of sugar composition in some kinds of natural honey and winter stores processed by bees from starch syrup. J. Apic. Sci. 2007, 51, 23-38. 
9. LeBlanc, B.W.; Eggleston, G.; Sammataro, D.; Cornett, C.; Default, R.; Deeby, T.; St. Cyr, E. Formation of hydroksymethylfurfural in domestic High-Fructose Corn Syrup and its toxicity to the honey bee (Apis mellifera). J. Agric. Food Chem. 2009, 57, 7369-7376. [CrossRef]

10. Sammataro, D.; Weiss, M. Comparison of productivity of colonies of honey bees, Apis mellifera, supplemented with sucrose or fructose corn syrup. J. Insect Sci. 2013, 13, 1-13. [CrossRef]

11. Semkiw, P.; Skubida, P. Suitability of starch syrups for winter feeding of honeybee colonies. J. Apic. Sci. 2016, 60, 141-151. [CrossRef]

12. Matescu, C.; Savu, V.; Sapcaliu, A.; Radoi, I.; Negoita, C. The influence of corn syrup based solid food supplements during the inactive (winter) season upon the evaluation of major bacterial diseases in bees. Bul. Univ. Agric. Sci. Vet. Med. Anim. Sci. Biotechnol. 2015, 72, 169-172. [CrossRef]

13. Krainer, S.; Brodschneider, R.; Vollmann, J.; Crtailsheim, K.; Riessberger-Galle, U. Effect of hydroksymethylfurfural (HMF) on mortality of artificially reared honey bee larvae (Apis mellifera carnica). Ecotoxicology 2016, 25, 320-328. [CrossRef] [PubMed]

14. Abou-Shaara, H.F. Effects of various feeding choices on survival and tolerance of honey bee workers to low temperature. J. Entomol. Acarol. Res. 2017, 49, 6200. [CrossRef]

15. Capuano, E.; Fogliano, V. Acrylamide and 5-hydroksymethylfurfural (HMF): A review on metabolism, toxicity, occurrence in food and migration strategies. LWT 2011, 44, 793-810. [CrossRef]

16. Śliwińska, A.; Przybylska, A.; Bazylak, G. Wpływ zmian temperatury przechowywania na zawartość 5-hydroksymetylofurfuralu w odmianowych i wielokwiatowych miodach pszczelich. Bromatol. Chem. Toksyk. 2012, 45, 271-279.

17. Kowalski, S.; Łukasiewicz, M.; Duda-Chodak, A.; Zięć, G. 5-Hydroxymethyl-2-Furfural (HMF)-Heat-Induced Formation, Occurrence in Food and Biotransformation-a Review. Polish J. Food Nutr. Sci. 2013, 63, 207-225. [CrossRef]

18. Shapla, U.M.; Solayman, M.; Alam, N.; Khalil, M., I; Gan, S.H. 5-hydroxymethylofurfural (HMF) levels in honey and other food products: Effects on bees and human health. Chem. Cent. J. 2018, 12, 35. [CrossRef]

19. Farag, M.R.; Alagawany, M.; Bin-Jumah, M.; Othman, S.I.; Khafag, A.F.; Shaheen, H.M.; Samak, D.; Shehata, A.M.; Allam, A.A.; Abd El-Hack, M.E. The Toxicological Aspects of the Heat-Borne Toxicant 5-Hydroxymethylfurfural in Animals: A Review. Molecules 2020, 25, 1941. [CrossRef]

20. Lee, H.S.; Nagy, S. Relative reactivities of sugars in the formation of 5-hydroxymethylfurfural in sugar-catalyst model systems. J. Food Process. Preserv. 1990, 14, 171-178. [CrossRef]

21. Frizzera, D.; Del Fabbiro, S.; Ortis, G.; Zanni, V.; Bortolomeazzi, R.; Nazzi, F.; Annoscia, D. Possible side effects of sugar supplementary nutrition on honey bee health. Apidologie 2020, 51, 594-608. [CrossRef]

22. Bailey, L. The effect of acid-hydrolysed sucrose on honeybees. J. Apic. Res. 1966, 5, 127-136. [CrossRef]

23. Jachimowicz, T.; El Sherbiny, G. Zur Problematic der Verwendung von Invertzucker für die Bienenfütterung. Apidologie 1975, 6, 121-143. [CrossRef]

24. Brodschneider, R.; Crailsheim, K. Nutrition and health in honey bees. Apidologie 2010, 41, 278-294. [CrossRef]

25. Van der Zee, R.; Pisa, L. Bijensterfte 2009-10 en toxische invertsuikersiroop. Ncb Rapp. 2010, 2, 1-15. Available online: http:/ /www.be emonitoring.org/Downloads/Bijensterfte\%202009-0_en\%20toxische_\%20invertsuikersiroop.pdf (accessed on 15 March 2016).

26. Zirbes, L.; Nguyen, B.K.; de Graaf, D.C.; De Meulenaer, B.; Reybroeck, W.; Haubruge, E.; Saegerman, C. Hydroxymethylfurfural: A possible emergent cause of honey bee mortality? J. Agric. Food Chem. 2013, 61, 11865-11870. [CrossRef] [PubMed]

27. Gregorc, A.; Jurišić, S.; Sampson, B. Hydroxymethylfurfural affects caged honey bees (Apis mellifera carnica). Diversity 2020, 12, 18. [CrossRef]

28. Tosi, E.; Ciappini, M.; Lucero, E.R.H. Honey thermal treatment effects on hydroxymethylfurfual content. Food Chem. 2020, 77,71-74. [CrossRef]

29. Fallico, B.; Zappala, M.; Arena, E.; Verzera, A. Effects of conditioning on HMF content in unifloral honeys. Food Chem. 2004, 85, 305-313. [CrossRef]

30. Zappala, M.; Fallico, B.; Arena, E.; Verzera, A. Methods for the determination of HMF in honey: A comparison. Food Control 2005, 16, 273-277. [CrossRef]

31. Fallico, B.; Arena, E.; Zappala, M. Degradation of 5-hydroksymethylfurfural in honey. J. Food Sci. 2008, 73, 625-631. [CrossRef]

32. Fallico, B.; Arena, E.; Zappala, M. Prediction of honey shelf life. J. Food Qual. 2009, 32, 352-368. [CrossRef]

33. Arena, E.; Ballistreri, G.; Tomaselli, F.; Fallico, B. Survey of 1,2-dicarbonyl compounds in commercial honey of different floral origin. Food Sci. 2011, 76, C1203-C1210. [CrossRef] [PubMed]

34. Laura, S.; Muste, S.; Tofana, M.; Suharoschi, R. Changes of hydroxymethylofurfural In heated honey. Agricultura 2013, 87, 101-104. [CrossRef]

35. Persano Oddo, L.; Piro, R. Main European unifloral honeys: Descriptive sheets. Apidologie 2004, 35, 38-81. [CrossRef]

36. Szczęsna, T.; Rybak-Chmielewska, H.; Waś, E.; Kachaniuk, K.; Teper, D. Characteristic of Polish unifloral honeys. I. Rape honey (Brassica napus var. oleifera Metzger). J. Apic. Sci. 2011, 55, 111-119.

37. Rybak-Chmielewska, H.; Szczęsna, T.; Waś, E.; Jaśkiewicz, K.; Teper, D. Characteristics of Polish unifloral honeys. VI. Honeydew honey, mainly Abies alba L. J. Apic. Sci. 2013, 57, 51-59.

38. Waś, E.; Rybak-Chmielewska, H.; Szczęsna, T.; Kachaniuk, K.; Teper, D. Characteristics of Polish unifloral honeys. II. Lime honey (Tilia spp.). J. Apic. Sci. 2011, 55, 121-128. 
39. Waś, E.; Rybak-Chmielewska, H.; Szczęsna, T.; Kachaniuk, K.; Teper, D. Characteristics of Polish unifloral honeys. III. Heather honey (Calluna vulgaris L.). J. Apic. Sci. 2011, 55, 129-136.

40. Machado De-Melo, A.A.; Almeida-Muradian, L.B.; Sancho, M.T.; Pascual-Mate, A. Composition and properties of Apis mellifera honey: A review. J. Apic. Res. 2018, 57, 5-37. [CrossRef]

41. Sancho, M.T.; Muniategui, S.; Huidobro, J.F.; Simal Lozano, J. Aging of honey. J. Agric. Food Chem. 1992, 40, 134-138. [CrossRef]

42. Ruiz-Matute, A.I.; Weiss, M.; Sammataro, D.; Finely, J.; Sanz, M.L. Carbohydrate composition of high-fructose corn syrups (HFCS) used for bee feeding: Effect on honey composition. J. Agric. Food Chem. 2010, 58, 7317-7322. [CrossRef]

43. Szczęsna, T.; Waś, E.; Semkiw, P.; Skubida, P.; Jaśkiewicz, K.; Witek, M. Changes of Physicochemical Properties of Starch Syrups Recommended for Winter Feeding of Honeybees During Storage. Agriculture 2021, 11, 335. [CrossRef]

44. Bogdanov, S.; Martin, P.; Lúllmann, C. Harmonized methods of the European Honey Commission. Apidologie 1997, 28, 1-59.

45. CODEX STAN 12-1981. Codex Alimentarius. Revised Codex Standard for Honey; Rev. 1 (1987), Rev. 2 (2001). 2001. Available online: http: / / www.fao.org/fao-who-codexalimentarius/sh-proxy/en/?lnk=1\&url=https\%253A\%252F\%252Fworkspace.fao.org\%252Fs ites\%252Fcodex\%252FStandards\%252FCXS\%2B12-1981\%252FCXS_012e.pdf (accessed on 19 April 2021).

46. Council Directive 2001/110/EC of 20 December 2001 relating to honey. OJEC 2002, L10, 47-52.

47. Teixido, E.; Núňez, O.; Santos, F.J.; Galceran, M.T. 5-Hydroxymethylfurfural content in foodstuffs determined by micellar electrokinetic chromatography. Food Chem. 2011, 126, 1902-1908. [CrossRef] [PubMed]

48. Nicolov, P.Y.; Yaylayan, V.A. Reversible and covalent binding of 5-(hydroxymethyl)-2-furaldehyde (HMF) with lysine and selected amino acids. J. Agric. Food Chem. 2011, 59, 6099-6107. [CrossRef] [PubMed]

49. Szczęsna, T.; Waś, E.; Skubida, P.; Semkiw, P. Changes of Physicochemical Properties of Saccharose Syrup during Storage. Unpublished Work. 2021. 